archives-ouvertes

\title{
Gabbro layering induced by simple shear in the Oman ophiolite Moho transition zone
}

David Jousselin, Luiz F.G. Morales, Marie Nicolle, Aurore Stephant

\section{To cite this version:}

David Jousselin, Luiz F.G. Morales, Marie Nicolle, Aurore Stephant. Gabbro layering induced by simple shear in the Oman ophiolite Moho transition zone. Earth and Planetary Science Letters, Elsevier, 2012, 331-332, pp.55-66. 10.1016/j.epsl.2012.02.022 . hal-02379478

\section{HAL Id: hal-02379478 \\ https://hal.univ-lorraine.fr/hal-02379478}

Submitted on 25 Nov 2019

HAL is a multi-disciplinary open access archive for the deposit and dissemination of scientific research documents, whether they are published or not. The documents may come from teaching and research institutions in France or abroad, or from public or private research centers.
L'archive ouverte pluridisciplinaire HAL, est destinée au dépôt et à la diffusion de documents scientifiques de niveau recherche, publiés ou non, émanant des établissements d'enseignement et de recherche français ou étrangers, des laboratoires publics ou privés. 
1 Gabbro layering induced by simple shear in the Oman ophiolite Moho transition 2 zone

4 David Jousselin ${ }^{1}$, Luiz F. G. Morales ${ }^{2}$, Marie Nicolle ${ }^{1}$, and Aurore Stephant ${ }^{1}$

5 1: Université de Lorraine, CRPG, 54501 Vandoeuvre les Nancy, France

6 2: Deutsches GeoForschungsZentrum (GFZ), Section 3.2 Telegrafenberg, 14473, Potsdam,

7 Germany

9 Abstract

11 We investigate the origin of modal layering in gabbro lenses of the Moho transition zone in the Oman ophiolite with a microstructural study. Gabbro lenses exhibit a shape preferred

13 orientation of plagioclase crystals, that are euhedral and devoid of any intracrystalline

14 deformation. This texture and field kinematic indicators show a strong simple shear

15 deformation in magmatic conditions. The parallelism of the lineation in gabbros and the

16 plastic lineation of the host dunite indicate that their development is contemporaneous, and

17 that the magmatic features are passively coupled to the solid-plastic flow of the host mantle.

18 We also found undeformed-isotropic and weakly deformed-roughly layered gabbro. The host

19 rock is plagioclase and clinopyroxene impregnated dunite; it contains euhedral plagioclase

20 suggesting that some grains crystallized in suspension. There is no clear boundary between

21 the gabbro and the host rock; on the contrary, the limit is diffuse, with increasing plagioclase

22 and clinopyroxene content from the dunite to the gabbro over tens of meters. This suggests

23 that the gabbro corresponds to melt impregnated dunite. We defined 4 gabbro types, from

24 unlayered (type 1) to well layered (type 4) with progressively more continuous and distinct

25 layers. We characterized deformation with crystal shape and crystallographic preferred 
orientation (CPO) measurements. Unlayered samples have a random fabric; type 2 have a very weak shape fabric and planar CPO, defined by olivine and plagioclase (010) planes; type 3 have a weak fabric, with a lineation defined by the [001] olivine axis and the [100] plagioclase axis, which reflects the shape fabric; type 4 have a strong shape fabric and CPO, with a lineation defined by the [100] olivine and plagioclase axis. We interpret the progression from isotropic to clear S-L fabrics as a result of increasing deformation imposed by the flowing host mantle. The type 2 gabbros must result from compaction; with increasing simple shear, the lineation is developed in type 3 samples; finally, with lower melt content, suspension flow switches to plastic deformation in the olivine-rich layers, leading to plastic olivine fabrics in type 4 samples. We deduce that layering originates from simple shear, which other studies show induces strong segregations in suspended particles, and plastically deformed rocks. To build the isotropic stage, melt must accumulate faster than the deformation, suggesting that melt is extracted by dikes.

\section{Introduction}

Layering in igneous rocks is a focal issue because it is related to magma emplacement and evolution. Modally layered gabbros in ophiolites are regarded as relics of the low velocity zone beneath the axial melt lens reported at fast oceanic spreading ridges (e.g. Detrick et al, 1987; Caress et al, 1992), and represent a key section in the ridge melt plumbing system. Several models have been proposed to explain the formation of layered gabbro in ophiolites. The earliest models advocated the accumulation of crystals in a magma chamber (e.g. Smewing, 1981); others proposed that layering results from the tectonic transposition of melt either sinking from above as it crystallizes from the melt lens (Quick and Denlinger, 1993 known as the "glacier model") or flowing from beneath as it is extracted from the mantle 
(Nicolas et al, 1988). The model of Henstock et al (1993) is a variation of the gabbro glacier model where layering originates from cyclic melt sills rather from than sedimentation at the bottom of a permanent melt lens followed by deformation. Alternatively, layers may represent stacked sill intrusions (Boudier et al, 1996a; Kelemen et al, 1997a; Lissenberg et al, 2004; known as "sheeted sill model"). No consensus emerges from these models, each implies different melt paths, times of residence and extents of interaction with the host rock. One problem that hinders our knowledge of the origin of modal layering is that we see only the final products, i.e. the layered gabbros, and have no trace of evolutional stages since the melt was first emplaced. This may be because transitional stages are brief relative to geological time scales, and thus are rarely fossilized. The Oman ophiolite may enable to capture such short lived processes which could have occurred at the ridge axis itself. Mapping of mantle diapirs and dike distribution show that a spreading axis which produced a $50 \mathrm{Km}$ wide portion of oceanic crust -similar to that of fast spreading-ridges- is preserved in the southern massifs (Ceuleneer et al, 1988; Boudier et al, 1997). The Moho transition zone (MTZ) in the Oman ophiolite is a few meters to a few hundreds meters thick, and is characterized by gabbro lenses imbedded in dunite, plagioclase and clinopyroxene impregnated dunite, and depleted harzburgite (Boudier and Nicolas, 1995). Identification of this unit as the uppermost mantle is based on the recognition of mantle fabrics and the occurrence of residual orthopyroxene in the MTZ, showing that dunite results from dissolution of harzburgite pyroxene by a circulating melt (Sinton, 1977; Nicolas, and Prinzhofer, 1983). The gabbro lenses in the MTZ are indistinguishable from layered gabbros in the lower crust; they have the same type of modal layering and chemical composition (Kelemen et al, 1997a), which suggests that they formed in the same way. The presence of melt at the MTZ is now recognized by a growing number of marine geophysical studies at fast and intermediate spreading ridges (Garmany, 1989; Crawford and Webb, 2002; Nedimovic et al, 2005), underscoring the importance of 
understanding the structure of the MTZ. This paper presents new field observations and a microstructural study of gabbroic rocks in the MTZ associated with the well-known Maqsad mantle diapir (Ceuleneer et al, 1988; Jousselin et al, 1998). We distinguish four types of samples which represent different evolutionary stages of the gabbro layering. Because universal-stage measurements are time consuming and tedious to acquire, especially for plagioclase, published crystallographic preferred orientation (CPO) data in Oman layered gabbro are limited to seven examples dispersed in four studies: one in Benn and Allard, 1989; three in Boudier and Nicolas, 1995; one in Boudier et al, 1996a with olivine only; two in Yaouancq and MacLeod, 2000, with plagioclase only; the latter also contain fabric data for six foliated gabbros of the unlayered upper part of the gabbro section. Of the five olivine CPOs, two are in MTZ gabbro lenses (Boudier and Nicolas, 1995), the others are in the crust. Fifteen more plagioclase fabrics were measured in studies devoted to anorthosite layers in the foliated upper crust (Morales et al, 2011). The use of a scanning electron microscope (SEM) equipped with an electron back-scattered diffraction (EBSD) system allowed us to gather a dataset of 27 olivine CPOs and 35 plagioclase CPOs. The acquisition of this unprecedented dataset was essential to reveal possible deformation stages within the different types of gabbro observed. We also characterized deformation by crystal shape preferred orientation measurements in 7 thin sections. Deformation analysis coupled to sample distribution, and description of the layering, permit us to discuss the origin of gabbro layering and magma extraction processes.

\section{Geological stetting and field observations}

The MTZ in ophiolites represents a level where part of the melt extracted from the mantle is collected, circulates and partially crystallizes, before feeding the overlying oceanic crust 
101 (Karson and Collins, 1984; Boudier and Nicolas, 1995; Sano and Kimura, 2007). It offers the opportunity to observe the distribution of melt ponding and percolating in a deforming matrix. In the Oman ophiolite, the development of a thick (>100 meters) MTZ is related to the presence of mantle diapirs that carry the melt from below (Nicolas, et al, 1996; Godard et al, 2000). The Maqsad mantle diapir region has been extensively studied, providing a well-

106 known general framework for detailed studies of the MTZ and layered gabbro lenses

107 (Rabinowicz et al, 1987; Ceuleneer et al, 1988; Boudier and Nicolas, 1995; Kelemen et al, 108 1997a; Jousselin et al, 1998; Koga et al, 2001). The crust-mantle interface (Moho) in this area 109 is nearly horizontal, and dikes in the sheeted dike system are vertical. The region can thus be 110 viewed as a paleospreading center dissected by erosion, without any subsequent deformation.

112 Gabbro lenses in the MTZ are always magmatically deformed (i.e. with a grain shape 113 preferred orientation of anisometric and euhedral crystals ascribed to flow in the dense 114 suspension; e.g. Benn and Allard, 1989; Nicolas, 1992; Yaouancq and MacLeod, 2000), 115 without sample-scale evidence of plastic deformation (such as augen pyroxene grains), and 116 are usually subhorizontal. Lens thickness varies from a few centimeters to tens of meters, with 117 a horizontal extent of a few meters to a hundred meters; many lenses are $<1 \mathrm{~m}$ thick, and 118 some tend to cluster in the upper part of the MTZ. Layer thicknesses vary from a few 119 millimeters to a few tens of centimeters. Graded layers are common features (about 20-25\% 120 of 200 layers in outcrops of our field study), but the strong majority of individual layers tend

121 to be homogeneous from the base to the summit, with sharp limits at each boundary. Bulk and 122 layer composition are variable. Leucotroctolite bulk compositions seem dominant and 123 clinopyroxene-rich layers seem more rare than those rich in olivine or plagioclase. Table 1 124 shows representative variations of the layer composition. Although we are not aware of any 125 rigorous systematic measurements of lens and layer dimensions and modal compositions, our 
observations agree with field impressions and the few sample descriptions provided by other workers (Boudier and Nicolas, 1995; Boudier et al, 1996a; Kelemen et al, 1997a; Korenaga et al, 1997). Nevertheless, the presence of several tens of meters thick lenses, and the relative importance of graded layers (qualified as an important feature in Kelemen et al, 1997a), seem overestimated. All structural features are generally concordant: the contact of gabbro lenses with the host dunite, modal layering (Fig. 1), and the gabbro magmatic foliation and lineation are all usually parallel to the asthenospheric plastic foliation and lineation of the host dunite. However several outcrops with less deformed gabbros show semi-discordant lenses with

134 irregular shapes and rough layering, or discordant layers, and a few outcrops show isotropic 135 gabbros, troctolites, and olivine-rich troctolite patches (Fig. 2). In particular, one outcrop 136 (N22 59'32", E5759'46", called hereafter the Khilah outcrop) presents a spectacular case of

137 mostly isotropic gabbros, extending over five hundred meters (Fig. 3). The outcrop contains a 138 few 1 to 20 meters wide zones with poorly layered gabbros. When it is present, layering is 139 parallel to the plastic foliation of the host peridotite observed 20 to 100 meters away. Except 140 for the roughly layered zones, and a few randomly oriented heterogeneities (mainly

141 centimeter sized dunite bodies) (Fig. 2B), the gabbro seems a relatively homogeneous mix of 142 plagioclase (60-80\%), olivine (10-30\%) and clinopyroxene (0-20\%) (Fig. 2A). The transition 143 from the host peridotite (mainly plagioclase and clinopyroxene impregnated dunite) to the 144 isotropic gabbro is diffuse, with increasing plagioclase and clinopyroxene impregnations 145 towards the center of the outcrop over few meters. In parts of the impregnated dunite, 146 plagioclase crystals are automorphic, suggesting that there was enough melt for the crystals to 147 grow in suspension (Fig. 4A). When plagioclase and clinopyroxene reach 25\%, they contour 148 and isolate olivine grains in dunite and the rock becomes isotropic (Fig. 4B). This near 149 poikilitic texture (with olivine crystals larger than oikocrysts) gives way to phaneritic textures 
with a hypidiomorphic granular fabric when the plagioclase and clinopyroxene fraction

151 increases and the rock becomes a gabbro.

153 The general characteristics of gabbro lenses bear similarities with those of plagioclase and

154 clinopyroxene impregnations in the MTZ dunite (Fig 5). In the impregnated dunite,

155 clinopyroxene and plagioclase grains are devoid of any intracrystalline deformation, but they

156 have an elongated shape, parallel to the plastic stretching lineation of the host dunite, with

157 more elongated grains, and stronger shape preferred orientation associated with the stronger

158 olivine CPOs in the dunite, suggesting crystals filled melt pockets which shape was governed

159 by strain (Jousselin and Mainprice, 1998). As for the layered gabbro lenses versus the

160 isotropic gabbro, field observations of well transposed melt impregnations parallel to the

161 foliated dunite are much more common than isotropic impregnations within poorly foliated

162 dunite; however isotropic impregnations are not rare. All strongly elongated impregnations

163 occur in dunite whereas some of the untransposed ones occur in residual harzburgite, where a

164 few corroded orthopyroxene grains can be observed. Some of the impregnations are

165 continuous with the tip of gabbro lenses or form diffuse contacts with gabbro lenses (Fig. 5;

166 figure 1a in Boudier et al, 1996a) suggesting that they are cogenetic.

\section{New structural observations, and kinematic analysis}

170 Kelemen et al. (1997a) assume that deformation by simple shear would have obliterated

171 graded layers, and conclude that most deformation must have been pure shear (flattening

172 during compaction). This would suggest that the gabbro lenses were not affected by the

173 surrounding mantle flow and therefore would be late or off-axis features, whereas their study

174 rightfully points to chemical compositions that argue that the lenses were emplaced on-axis. 
175 However, we find numerous and robust indicators that gabbro lenses and the host rock

176 recorded a strong simple shear deformation (Fig. 6), except for the local isotropic zones

177 aforementioned: (i) well developed lineation in the foliation plane, (ii) folds in the gabbro

178 lenses with an axis consistently parallel to the lineation (Fig. 6A-B), (iii) synmagmatic normal

179 faults with an azimuth at high angle with the magmatic lineation and S/C shear bands (Fig

180 6C-D; Nicolas, 1992), (iv) the frequent CPO measurements in the host dunite, that show [100]

181 crystallographic axis of olivine at a small angle to the lineation (Fig. 7A; Ben Ismail and

182 Mainprice, 1998; Dijkstra et al, 2002). In some cases, an obliquity of the olivine and

183 plagioclase shape preferred orientation with the layering is discernible (Fig. 6E). This

184 evidence indicates moderate simple shear deformation, but in most cases, all structures are

185 parallel, pointing to a very large strain, including in the graded layers (Nicolas, 1992). It

186 should also be noted that a 50\% compaction, as calculated by Browning (1984) and used by

187 Kelemen et al (1997a), seems insufficient to produce a strong foliation (Higgins, 1991). The

188 parallelism of the shape fabric in melt impregnated dunite, the magmatic lineation in gabbros,

189 and the plastic lineation of the host dunite, indicate that their development is

190 contemporaneous, and that the magmatic features are passively coupled to the plastic flow of

191 the surrounding peridotitic matrix.

192

\section{4. Microstructural analysis}

\subsection{Gabbro layering and shape preferred orientation}

We present a microstructural study of samples of the MTZ, with an emphasis on the preserved cases of isotropic gabbros, and weakly layered samples that may represent the earliest 
samples in the Khilah outcrop, and 52 others in its vicinity (Fig 3). Four types of samples

201 were distinguished: type 1 is characterized by the absence of layering (Fig. 2A-B); type 2 shows weakly defined layers which can be followed over few centimeters (Fig. 2C-D); type 3 shows more strongly defined layers, still with diffuse or wavy limits (Fig.2E-F); the more common type 4 corresponds to the presence of very well defined layers with sharp and straight limits (Fig.1). Type 3 layers can rarely be followed over two meters, and type 4 layers may be followed over several meters. All samples display a magmatic texture; plagioclase show euhedral magmatic laths, and a few are twinned, which implies sufficient freedom for crystals to rotate without undergoing plastic deformation. Clinopyroxene is tabular or roundshaped with no evidence of deformation. In type 1-3 samples, some of the olivine grains show 210 clear crystallographic faces suggesting a cumulative origin, or overgrowth around the edges 211 of mantle xenocrysts (Boudier, 1991). In all samples, olivine does not show any dynamic recrystallization, but some grains have undulose extinction suggesting light plastic deformation. Field observations of crystal alignment and aggregate elongation indicate that deformation increases from type 1 to type 4 samples. To evaluate the importance of the shape 215 fabric, we performed shape preferred orientation analyses based on hand drawings of seven 216 thin sections, sectioned parallel to the lineation and perpendicular to the magmatic foliation 217 (XZ plane). Two type 1 samples were analyzed; as no foliation and lineation is visible in 218 these, the thin sections were cut parallel to the orientation of the nearest observable XZ plane 219 from nearby outcrops. For each crystal, we measured the longest chord connecting any two 220 points on the perimeter, and the orientation of this axis with respect to the $\mathrm{X}$ axis. As 221 anticipated, the two type 1 samples do not show any crystal shape preferred orientation; this was also checked on a thin section cut perpendicularly; preferred orientation in type 2 to 4 gradually changes from weak to strong (Fig 7B). 
227 Of sixty-two gabbro samples we collected, forty were chosen on the basis of their type variety 228 and freshness for CPO analysis. Phases and orientation were mapped using the SEM-EBSD 229 facility at Geosciences Montpellier (e.g. Fig. 1C) with a 45-100 $\mu \mathrm{m}$ grid spacing. Due to 230 alteration or lack of a mineral phase, we obtained 27 olivine CPO and 35 plagioclase CPO 231 usable measurements (100 measured grains per phase, except 5 cases with $>75$ measured 232 grains which were considered valid because the olivine fabric seemed unambiguous. Pole 233 figures are plotted with one point per grain. Grain counting was done manually, because 234 automatic counting from the map counts a single grain as several when it is cut by veins). 235 Alteration is particularly important in our weakly deformed samples, which choice is more 236 limited than for the type 4 samples; thus to reflect the variety of the microstructures while 237 insuring that enough grains are measured to obtain a valid CPO, eight parallel thin sections 238 were cut for two type 2 samples, and representative CPOs were obtained once the 239 measurements were compiled. Our study also includes 2 olivine CPOs in the MTZ host 240 dunites, measured with a universal stage. A selection of representative CPOs of olivine and 241 plagioclase is shown in Fig. 7; the full CPO dataset is available in online Supplementary 242 Information, including samples with specific patterns described below.

244 The two type 1 samples show random CPOs. The five type 2 samples show essentially planar 245 fabrics, where the (010) crystal faces of olivine and plagioclase define the magmatic foliation. 246 The type 2 olivine fabric is not regular, one seems random (07OD21B), in the other cases the 247 [001] axis draws a girdle in the foliation plane, and the [100] axis orientation is erratic, except 248 for one case (07OD44E) where it draws a girdle in the foliation plane. The plagioclase fabric 249 is better defined, with the [100] axis drawing a girdle in the foliation plane, even defining a 
weak lineation in two cases (07OD21B and 10-OM43I); the [001] axis orientation is imprecise, with a light tendency to lie in the foliation plane (clear for one sample: 07OD32). The type 3 samples have a more consistent CPO; both olivine (4 samples) and plagioclase (5 samples) show a lineation superimposed on the (010) foliation. In olivine, the [001] axis corresponds to the lineation, while [100] is perpendicular to it; in plagioclase, [100] corresponds to the lineation, and [001] has a somewhat erratic orientation. The type 4 samples have the same plagioclase $\mathrm{CPO}$ as type 3 samples; however, olivine fabrics are drastically different with very well defined [100] (010) CPOs, and a weak tendency of the [001] axes to concentrate near the Y axis, with one exception showing a [100] (001) fabric (10-OM42G3). Olivine CPOs in the host dunite show the classic [100] (010) mantle fabric (Ben Ismaïl and Mainprice, 1998).

\section{Interpretation and discussion}

\subsection{Comparison with sill models}

The model where modally layered gabbro of the lower crustal section formed in sills (Boudier et al, 1996; Kelemen et al, 1997a) is inferred on the analogy with gabbro lenses of the MTZ that are interpreted as sill intrusions. This interpretation relies on the common elongated silllike shape of the MTZ gabbro lenses (Fig. 1A) and the presence of graded layers that were thought to indicate a lack of deformation. We have shown that the gabbro lenses are strongly deformed (Fig. 6) and that lenses may have shapes that differ from those of simple sills (Fig. $2 \mathrm{H})$. Also there is no microstructural study showing that the layered gabbro lenses have intrusive contacts, or observations of layered gabbro lenses branching with dikes or any rootlike bodies tectonically transposed after emplacement, which would support that the lenses 
are the remains of sills. Unlike what can be observed in Oman, Bedard (1990; 1993) describes

276 sharp intrusive contacts, with reaction rims and host rock xenoliths in gabbro sills of the Bay

277 of Island ophiolite. In the Annieopsquotch ophiolite, Lissenberg et al (2004) describe

278 dendritic crystals and comb structures in modally layered gabbro sills, and note that the

279 gabbros do not show any fabric. It is surprising that no such clear symptomatic criteria for a

280 sill origin is present in Oman. This might be because of a lack of compositional or thermal

281 disequilibrium between the lenses and the host rock, but even rare layered sills corresponding

282 to the dying stage of the Oman magmatism are not found. On the contrary, many gabbro

283 lenses have diffuse contacts (Fig. 5) rather than sharp ones, the tip of the lenses often show a

284 progressive transition from the gabbro to the host impregnated dunite over a few centimeters,

285 and all of the layered gabbro have a clear fabric. This suggests that the sill model is not

286 applicable to many of the gabbro lenses of the Oman ophiolite MTZ. Also, the presence of

287 euhedral plagioclase within the impregnated dunite (Fig. 4A) shows that suspension flow is

288 not confined within the lenses, and that the lenses may result from a segregation rather than

289 represent the remains of the melt conduits.

5.2. Melt emplacement.

With its diffuse limits (Fig. 3C), the gabbro of the Khilah outcrop clearly does not represent a

294 sill intrusion. The transition from the impregnated dunite to the gabbro, and the presence of

295 dunite patches within the gabbro strongly suggest that the gabbros represent zones where

296 impregnating melt crystallized great volumes of plagioclase and to a lesser extent

297 clinopyroxene, to the point where the petrologic designation of the rock switches from

298 plagioclase-dunite to troctolite or gabbro although it is in essence a massively impregnated

299 dunite. A consequence of this interpretation is that a part of the olivine grains in the gabbro 
must be mantle xenocrysts. The textures, the large grain size (1 to $5 \mathrm{~mm}$ ), and the coupling of

301 gabbro layers orientation with asthenospheric mantle flow show that melt emplacement at the

302 Khilah outcrop is contemporaneous with mantle flow and thus must be ascribed to ridge

303 processes. This outcrop is structurally above isotropic melt impregnations in depleted

304 harzburgite at the Mahram village, above the Maqsad mantle diapir (Fig. 3). It is beneath a $>2$

$305 \mathrm{Km}$ wide zone, where gabbros at the base of the crustal section are roughly layered, and

306 resemble those observed at the Khilah outcrop. Isotropic and poorly layered gabbro blocks are

307 particularly abundant in riverbeds near the Khilah outcrop but are also found elsewhere,

308 suggesting that this type of outcrop is not unique. The position at the apex of the mantle

309 diapir, probably centered on the inferred paleoridge axis, may explain why the whole area

310 shows several outcrops that are not strongly affected by the diverging ridge flow. This

311 situation raises the question of how isotropic gabbro bodies evolve when they are not

312 fossilized in this state and endure the deformation imposed by the host rock; the layered

313 gabbro lenses are the only obvious candidates for the possible result.

\subsection{Fabric evolution}

The poikilitic textures in impregnated dunite show olivine grains that are free to rotate (Fig. 4b), implying that melt reached the critical melt fraction (near 30\%, Van der Molen and Paterson, 1979) where the solid matrix is disaggregated by the melt and the fabric is lost, thus

320 forming the type 1 gabbro. Four isotropic CPOs in melt impregnated harzburgite and dunite 321 samples have been reported before (Boudier et al, 1996; Jousselin et al, 1998; Jousselin and 322 Mainprice, 1998), and interpreted in this manner; however in these cases only a small fraction of plagioclase and clinopyroxene was precipitated from the melt in the residual dunite, thus

324 the modal composition was not shifted towards that of a gabbro. The situation observed in the 
Khilah outcrop is rare because it shows a stage that can only be ephemeral. As melt progresses through the solid dunitic matrix, it fills more space, thus the fluid pressure will drop, and the melt mush will start to compact. This will lead to fading of the type 1 stage and emergence of a planar fabric which is exactly what is observed in type 2 samples.

As melt fraction decreases and more transient solid chains form and interact, coupling with

331 the simple shear imposed by the surrounding mantle flow is more efficient, and leads to the development of a stronger magmatic lineation in the olivine and plagioclase $\mathrm{CPO}$ as seen in type 3 samples. [001] (010) olivine CPO is generated by magmatic flow (Benn and Allard, 1988), or may be favored by plastic deformation in the presence of melt (Holtzmann et al, 2003) or by mantle hydratation (Jung and Karato, 2001). The euhedral shape, the preferred shape orientation and its correlation with the CPO, and the context of the magmatic rock with magmatic texture for plagioclase, where most olivine grains are embedded in plagioclase and clinopyroxene grains that are themselves not deformed, suggest that at this stage plastic intracrystalline deformation is not a major factor to produce the CPO. We interpret the $340[001](010)$ olivine CPOs in type 3 as similar to the magmatic fabric in a sample of Oman 341 layered gabbro of the crustal section (Benn and Allard, 1988). Note that the term "magmatic" refers to the physical conditions required to orient crystals without any intracrystalline 343 deformation; it does not refer to the olivine origin which can be cumulative or mantellic. As 344 the [001] axis is the longest axis in euhedral olivine, it aligns with the flow, and the CPO 345 reflects the shape fabric. The [100] (010) plagioclase CPO in type 3 and type 4 samples 346 compare well with previously reported magmatic fabrics (see review in Benn and Allard, 347 1988), and the lack of evidence for plastic deformation leaves no doubt that the plagioclase 348 fabrics are of magmatic origin. 
Type 4 samples show a [100](010) olivine CPO which corresponds to the classic high-

351 temperature gliding system. The unique case of [100] (001) CPO also corresponds to a less

352 common high-temperature gliding system; it has been reported in two harzburgite samples of

353 the Maqsad diapir (unpublished personal data), a harzburgite at the Garret transform (Cannat,

354 et al, 1990), Hess Deep (Boudier et al, 1996b), and dunite associated with chromite pods in

355 the New Caledonia ophiolite (Cassard et al, 1980); i.e. cases where the peridotite is associated

356 with melt circulation. We now try to understand how such a plastic fabric can be generated in

357 gabbros with a prominent magmatic texture. Boudier and Nicolas (1995) have reported [100]

358 (010) olivine CPOs for two strongly deformed gabbro samples; they classify the origin of

359 strain in olivine as questionable. Vernon (2000) notes that solid-state strain in the interstices

360 between undeformed and aligned crystals may assist rotation and alignment without plastic

361 deformation of the rotated crystals. While he considers observations where the solid-state

362 strain is thought to be minor, he also points out that it is unknown to what degree this process

363 can produce strong alignment of undeformed crystals. Indeed, in solid-state deformation,

364 large viscosity contrasts may also be present and mechanisms of particle orientation in

365 magmatic flow can also apply to the situation of rigid crystals embedded in a weak solid

366 matrix deforming plastically, such as amphiboles in a phyllite (Fergusson, 1979).

367 Experimental constraints for plagioclase deformation at high temperature suggest that olivine

368 is weaker than plagioclase at oceanic Moho conditions (Seront, 1993; Dimanov et al, 1998).

369 The possibility of deforming olivine plastically while plagioclase crystals remain undeformed

370 is enhanced by the strong segregation observed at this stage. We argue that as a critical

371 threshold of olivine connectivity is reached, olivine deformation rapidly switches from

372 magmatic to plastic. This last stage of deformation probably contributes to the layering

373 sharpening, as deformation must concentrate in the weakest layer: either melt (and possibly 
plagioclase) rich layers if enough melt is present within this layer, or more probably at this

375 last stage, olivine rich layers when the melt fraction is greatly reduced.

377 Once gabbro is fully crystallized, it must be under lithospheric conditions (i.e. mantle flow is

378 frozen). As no low temperature deformation is recorded, gabbro in lithospheric conditions

379 must simply drift away from the ridge axis and not be further deformed. Thus the strong

380 olivine plastic fabric must develop in a tight window at the asthenosphere/lithosphere

381 boundary, with little or no melt, where most of the deformation is accommodated by the

382 olivine rich layers. This implies that under high temperature conditions, and with the presence

383 of melt to enhance diffusion, simple shear is capable of erasing the pre-existing type 3 fabric

384 and of producing a new and strong plastic olivine CPO, within a few hundred meters of flow.

386 It is interestingly fitting that the samples with the largest fractions of clinopyroxene are type 3

387 and type 4 gabbros. For a parental MORB melt, clinopyroxene must be the last phase to 388 crystallize, at near $1160^{\circ} \mathrm{C}$ (Feig et al, 2006), when the mush is crystal-rich and the final

389 stages of deformation are reached. Still, more data are needed to establish a correlation

390 between modal composition and gabbro types, and we will see in the next section that modal 391 composition should be used with caution.

393 IODP hole 1309D, at the Mid-Atlantic ridge, traverses melatroctolites, troctolites and olivine

394 gabbros that might be viewed as similar to our samples. In the IODP hole, the olivine CPO is 395 thought to result from a mantle fabric modified by incoming melt, which corroded olivine 396 grain boundaries and penetrated along olivine tilt walls (Drouin et al, 2010). We do not think 397 that the fabrics of our samples are inherited from a previous mantle fabric. The IODP samples 398 show small olivine grains embedded in large plagioclase poikiloblasts; whereas in our 
samples, olivine crystals remain large, they do not show evidence for corroded boundaries,

400 and the plagioclase blades are not parallel to olivine tilt walls. Our outcrops top the

401 harzburgite section, whereas those of the IODP hole lie above evolved gabbro, which indeed

402 could provide an evolved melt able to dissolve olivine grains (Suhr et al, 2008). Finally, the

403 CPO analysis of the IODP samples relies on the relative concentration of maxima for each

404 crystallographic axis rather than their orientation as no $\mathrm{X}, \mathrm{Y}, \mathrm{Z}$ structural frame nor layering is 405 visible. It shows strong maxima for the [001] axis, which is not something we observe in our 406 samples.

408 Given the field relationships, and the coincidence of the different CPOs with aspects of the 409 shape fabric and layering in our samples, we argue that there is a continuum from type 1 410 samples where all mantle fabric heritage is lost, to type 4 samples where a new fabric is 411 produced (Fig. 8). In this last stage, where olivine is so segregated that it constitutes thin 412 dunite-like layers, the fabric is similar to the host dunite fabric to which it is coupled. We 413 suppose that many of the olivine crystals in the gabbro are of mantellic origin, but this is 414 deduced from the texture of type 1 samples, not from the fabric developed in type 3 and type 4154 samples, which could equally affect olivine of magmatic origin.

\subsection{Layering formation}

419 Most of the observed microstructures imply a strong simple shear deformation. We show that 420 layering does not predate shearing but is linked to the development of deformation. The CPOs 421 induced by the simple shear allow us to follow a continuous evolution of the deformation 422 which is correlated with the development of layering defined by type 1 to type 4 samples.

423 Field relations from type 1 to type 2 and 3 at the Khilah outcrop, and from the type 3 to type 4 
in other places are coherent with this evolution, and we think it is unlikely that the different types represent unrelated gabbro bodies. This idea is reinforced by the consideration that types 1 to 3 do not represent steady-state situations, and should be more deformed when they are not frozen at this stage.

Some of the reasons why simple shear in magmatic rocks can cause crystal and melt segregation are summarized by McBirney and Nicolas (1997). At least two processes are relevant to the generation of layering in our case: segregation of suspended solids (crystals) of differing sizes, and transposition of inhomogeneities. Similarly, the creation of layering by shearing is accepted in plastically deformed rocks, where a "massive" (unlayered) plutonic rock can turn into a layered gneiss, with better defined and thinner layers for more strongly deformed rocks (e.g. Myers, 1978). Also, shearing lead to transpose heterogeneities into lenticular beds (e.g. Ramsay and Graham, 1970) producing other layers. In addition there is a wide range of physical experiments and models that produce segregation in suspended particles, slurries, or granular material during simple shear deformation (e.g. Sokolowski and

439 Herrmann, 1992; Santra et al, 1996; Barentin et al, 2004; May et al, 2009), including 440 asymmetric layers (e.g. Komnik et al, 2004). These investigations indicate that any type of 441 difference in the particle species may lead to shear-induced segregation (Plantard et al, 2006). 442 This suggests that the complexity of crystal size, geometry, surface properties, and density 443 variations provide multiple factors favoring the generation of layers. On the basis of these 444 studies and our observations, we argue that a large fraction of gabbro layering can originate 445 from mechanical sorting during strong shearing and tectonic transposition of heterogeneities. 446 This model solves a paradox pointed by Koga et al (2001): the highly variable lithologies are 447 thought to arise via different degrees of crystal fractionation from a common parental melt; 448 however, the limited range of variability in olivine, plagioclase and clinopyroxene 
compositions suggests that the differences in extent of crystallization must be small. If layers

450 are created through mechanical sorting, their modal compositions do not reflect crystal

451 fractionation variations from a sequence to another, and it becomes possible to create various

452 lithologies from a single cumulate sequence.

\subsection{Timing and consequences on melt extraction process}

The small frequency of isotropic or weakly deformed gabbros suggests that they are transient features, which are not often preserved because they must be frozen in the short time lapse between emplacement and the shearing and tectonic transposition inexorably imposed by the surrounding mantle flow. This is coherent with the observation of residual harzburgite in

460 isotropic impregnations, where the orthopyroxene dissolution reaction with incoming melt is started but not completed, whereas transposed melt impregnations imply sufficient time for deformation to accumulate and thus longer melt residence within the rock, leading to resorbtion of all the orthopyroxene grains.

The isotropic stage implies that melt accumulated rapidly with respect to the mantle strain rate. How fast melt accumulates $(\mathrm{t})$ can be estimated by dividing the volume of melt that was present, by the melt flux from the melt feeding conduit. Considering that isotropic gabbro is distributed in a sphere with a diameter L equal to the length of the outcrop, and that the

469 minimum melt fraction corresponds to that required to disaggregate the solid framework 470 (30\%), it gives:

$471 \mathrm{t}=\left[4 / 3 \times(\mathrm{L} / 2)^{3} \times 0.3\right] /\left[V_{m} \times(D / 2)^{2} \times f\right]$

472 where $V_{m}$ is the ascending melt velocity, $D$ is the diameter of the melt conduit which we take 473 as circular, and $f$ is the melt fraction in this conduit. For a porous flow melt conduit, values on 
474 the order of one meter per year for $V_{m}$, one hundred meters for $D$, and one percent for $f$ seem 475 reasonable (Kelemen et al, 1997b). This gives a time of 250000 years. On the other hand, 476 gabbro layering seems to develop over distances less than a hundred meters as type 2 and 3 477 samples are present within the Khilah outcrop and at its outskirts. Given that the host dunite 478 flows at a velocity near the ridge spreading velocity or faster (Jousselin et al, 1998), for a 479 velocity around $10 \mathrm{~cm} /$ year we conclude that layering must develop over a time of about a 480 thousand years.

These numbers are not very precise, and are only intended to provide orders of magnitude. There was probably more than $30 \%$ melt present at the time of the formation of the Khilah outcrop, mantle foliation geometry and shear sense inversion beneath the Moho suggest that mantle flow is faster than ridge spreading rate (Ildefonse et al, 1995, Michibayashi et al, 2000), and dunite bands that are interpreted as relics of porous flow conduits, are often thinner than a hundred meters. So the discrepancy between the two results could be more important. This suggests that porous flow conduits cannot deliver melt fast enough to destroy

489 the solid framework of the host dunite and accumulate within a time window small enough to 490 not be affected by the host rock shearing. Another possibility is that melt was extracted from 491 dikes, as proposed by Nicolas (1986) for depth of 0 to $60 \mathrm{Km}$, and by Kelemen et al (1997b) 492 for very shallow mantle. It would take less than a year and a half for a $10 \mathrm{~cm}$ wide and $100 \mathrm{~m}$ 493 long dike, with a melt velocity of $1.5 \mathrm{~cm} / \mathrm{s}$ (Lago et al, 1982) to fill the necessary melt 494 volume. 
498 We investigate whether our model for the origin of layering in gabbro lenses of the MTZ is

499 adaptable to gabbro layers in the lower crust. Several lines of evidence suggest that this is 500 possible: recent marine geophysical investigation shows that the lower gabbros contain

501 similar local melt accumulations (Canales et al, 2009); Nicolas (1992) indicates that the 502 strong simple shear kinematic criteria are also ubiquitous in the layered gabbros of the crustal 503 section; we found type 2 and type 3 crustal gabbro at the inferred Maqsad paleoridge axis, and 504 out of the 3 published olivine CPOs measured in crustal layered gabbro, one presents a $505[001](010)$ fabric, typical of the type 3 gabbro (Benn and Allard, 1988). As the host rock is 506 not dunite, it is possible that the gabbro is devoid of olivine xenocrysts, and that melt recycles 507 plagioclase and clinopyroxene crystals of the host rock instead. On the other hand, wehrlite 508 crustal intrusions, which are rooted in the MTZ magmatic mush, may provide an olivine 509 xenocryst source, and may produce olivine rich layers when they are tectonically transposed 510 into concordance by the surrounding magmatic flow (Jousselin and Nicolas, 2000; Koga et al, $5112001)$.

\section{6. Conclusion}

515 We show that modal layering in gabbro lenses of the MTZ does not predate shearing but is 516 linked to the development of simple shear deformation, imposed by the surrounding mantle 517 flow. We collected the first extensive CPO dataset for these rocks, which allows us to follow 518 the coevolution of deformation and layering. We found three distinct deformation stages that 519 follow the emplacement of isotropic gabbro. First the melt mush is compacted, leading to 520 planar fabric (type 2 gabbros) and the emergence of a rough layering. Then simple shear leads 521 to a magmatic (driven by the shape of crystals in suspension) fabric (type 3 gabbros); at this 522 stage layer boundaries are very irregular and layer extension is limited to a couple meters at 
the most. In the last stage (type 4 gabbros), segregated olivine bands switch to hightemperature plastic fabrics, layer boundaries are very sharp and often can be followed over more than three meters. Most gabbro layers are fossilized at this last stage. To fossilize the initial isotropic stage, the melt input must be fast relative to the host dunite strain rate. This suggests that melt reached the MTZ through hydrofracturing dikes. When melt ceases to rise and ponds at the Moho level, textural analysis shows that it disperses through the host dunite and isolates olivine grains; as a result, a large fraction of the olivine grains in the layered gabbro lenses of the MTZ must be mantle xenocrysts.

532 The sheeted sill model for the Oman ophiolite gabbros mainly relies on the observation of

533 isolated layered gabbro lenses embedded in mantle dunite, which could not possibly derive

534 from the subsidence of a perched magma lens in the upper crust, and chemical constraints that imply that few layers represent isolated systems (sills or small convection cells within a magma chamber) (Browning, 1984, Kelemen et al, 1997a). On the other hand, gabbro glacier

537 models mainly focus on the identification of strong deformation in layered gabbros of the

538 lower crust. In this model, the deformation is related to the flow out of the magma lens

539 perched at the top of the crustal section, which was the only known magma lens at the time

540 these models were developed. A strong merit of our model is to be coherent with constraints

541 from the sheeted sill and the gabbro glacier models. Our model is not intended to describe the

542 dynamics of the whole magma chamber, but offers an explanation based on new data for the

543 formation of the gabbro layering at the base of the ridge magmatic system. 
547 This work was supported by the BQR program of INPL-Nancy Université. The authors are 548 grateful to Cédric Demeurie (Fr Eau-Sol-Terre) and Christophe Nevado (Géosciences

549 Montpellier) for the high-quality polished thin sections, David Mainprice for the use of his 550 softwares to plot pole figures, Andréa Tommasi for facilitating the access to the electron 551 microscopy facilities at Géosciences Montpellier, and the Directory of Minerals at the 552 Ministry of Commerce and Industry of the Sultanate of Oman for their hospitality. We also 553 wish to thank George Ceuleneer and an anonymous reviewer for helpful comments.

\section{References}

558 Barentin, C., Azanza, E., Pouligny, B., 2004, Flow and segregation in sheared granular 559 slurries, Europhys. Lett., 66, 139 doi: 10.1209/ep1/i2003-10191-2

560 Bédard, J.H., 1990, Cumulate recycling and crustal evolution in the Bay of Island ophiolite, J. 561 Geol., 99, 225- 249.

562 Bédard, J.H., 1993, Oceanic crust as a reactive filter: synkinematic intrusion, hybridization, 563 and assimilation in an ophiolitic magma chamber, western Newfoundland, Geology, 21, 7756480.

565 Benn, K., Allard, B., 1988, Preferred mineral orientations related to magmatic flow in 566 ophiolite layered gabbros, Journal of Petrology, 30, 925-946, doi:

$567 \quad 10.1093 /$ petrology/30.4.925.

568 Ben Ismaïl, W., Mainprice, D., 1998, An olivine fabric database: an overview of upper mantle 569 fabrics and seismic anisotropy, Tectonophysics, 206, 145-157, doi:10.1016/S0040$570 \quad 1951(98) 00141-3$. 
571 Boudier, F., 1991, Olivine xenocrysts in picritic magmas, an experimental and microstructural study, Contributions to Mineralogy and Petrology, 109, 114-123, doi: 10.1007/BF00687204. Boudier, F., Nicolas, A., 1995, Nature of the Moho transition zone in the Oman ophiolite, Journal of Petrology, 36, 777-796, doi:10.1093/petrology/36.3.777.

Boudier, F., Nicolas, A., Ildefonse, B., 1996a, Magma chambers in the Oman ophiolite: fed from the top and the bottom, Earth and Planetary Science Letters, 144, 239-250, doi:10.1016/0012-821X(96)00167-7.

Boudier, F., MacLeod, C.J., and Bolou, L., 1996b, Structures in peridotites from site 895, Hess Deep: implications for the geometry of mantle flow beneath the East Pacific Rise, In Mével, C., Gillis, K.M., Allan, J.F., and Meyer, P.S. (Eds.), Proc. ODP, Sci. Results, 147: College Station, TX (Ocean Drilling Program), 347-356.

Boudier, F., Nicolas, A., Ildefonse B., Jousselin, D., 1997, EPR microplates, a model for the Oman ophiolite, Terra Nova, 9, 79-82, doi: 10.1111/j.1365-3121.1997.tb00007.x.

Browning, P., 1984, Cryptic variations within the cumulate sequence of the Oman ophiolite: Magma chamber depth and petrological implications, Geol. Soc. London Spec. Publ. 13, 7182.

Canales, J.P., Nedimovic, M.R., Kent, G., Carbotte, S.M., Detrick, R., 2009, Seismic reflection images of a near-axis melt sill within the lower crust at the Juan de Fuca ridge, Nature, 460, 89-93, doi: 10.1038/nature08095.

Cannat, M., Bideau, D., Hébert, R., 1990, Plastic deformation and magmatic impregnation in serpentinized ultramafic rocks from the Garrett transform fault (East Pacific Rise), Earth and Planetary Science Letters, 101, 216-232, doi:10.1016/0012-821X(90)90155-Q.

Caress, D.W., Burnett, M.S., Orcutt, J.A., 1992, Tomographic image of the axial low-velocity zone at $12^{\circ} 50^{\prime} \mathrm{N}$ on the East Pacific Rise, Journal of Geophysical Research, 97, 9243-9263, doi: 10.1029/92JB00287. 
Cassard, D., 1980, Structure et origine des gisements de chromite du massif du Sud (ophiolite

597 de Nouvelle Calédonie). Guides de prospection, These de 3ème cycle, Univ. Nantes, Nantes.

598 Ceuleneer, G., Nicolas, A., Boudier, F., 1988, Mantle flow patterns at an oceanic spreading

599 center: the Oman ophiolite record, Tectonophysics, 151, 1-16, doi:10.1016/0040-

$600 \quad 1951(88) 90238-7$.

601 Crawford W., Webb, S.C., 2002, Variations in the distribution of magma in the lower crust 602 and at the Moho beneath the East Pacific Rise at $9^{\circ}-10^{\circ} \mathrm{N}$, Earth and Planetary Science 603 Letters, 203, 117-130, doi:10.1016/S0012-821X(02)00831-2.

604 Detrick, R.S., Buhl, P., Vera, E., Mutter, J., Orcutt, J., Madsen, J., Brocher, T., 1987, Multi605 channel seismic imaging of a crustal magma chamber along the East Pacific Rise, Nature, $606326,35-41$, doi:10.1038/326035a0.

607 Dijkstra A.H., Drury, M.R., Frijhoff R., 2002, Microstructures and lattice fabrics in the Hilti 608 mantle section (Oman Ophiolite): Evidence for shear localization and melt weakening in the 609 crust-mantle transition zone?, Journal of Geophysical Research, 107, 2270,

610 doi:10.1029/2001JB000458

611 Dimanov, A., Dresen, G., Wirth, R., 1998, High-temperature creep of partially molten 612 plagioclase aggregates, Journal of Geophysical Research, 103, 9651-9664, 613 doi:10.1029/97JB03742.

614 Fergusson, C., 1979, Rotations of elongate rigid particles in slow non-newtonian flows, 615 Tectonophysics, 60, 247-262, doi:10.1016/0040-1951(79)90162-8.

616 Drouin, M., Ildefonse B., Godard M., 2010, A microstructural imprint of melt impregnation in 617 slow spreading lithosphere: Olivine- rich troctolites from the Atlantis Massif, Mid- Atlantic 618 Ridge, 30N, IODP Hole U1309D, Geochem. Geophys. Geosyst., 11, Q06003, 619 doi:10.1029/2009GC002995 
620 Garmany, J., 1989, Acumulations of melt at the base of young oceanic crust, Nature, 340, $621 \quad 628-632$, doi:10.1038/340628a0.

622 Godard M., Jousselin, D., Bodinier, J.L., 2000, Relationships between geochemistry and 623 structure beneath a paleo-spreading centre: a case study of the mantle section in the Oman 624 ophiolite, Earth and Planetary Science Letters, 180, 133-148, doi:10.1016/S0012$625821 X(00) 00149-7$.

626 Henstock T.J., Woods, A.W., White, R.S., 1993, the accretion of oceanic crystal by episodic 627 sill intrusion, Journal of Geophysical Research, 98, 4143-4161, doi:10.1029/92JB02661.

628 Higgins, M., 1991. The origin of laminated and massive anorthosite, Sept iles layered 629 intrusion, Quebec, Canada. Contr. Miner. Petrol. 106, 340-54.

630 Holtzman, B.K., Kohlstedt, D.L., Zimmerman, M.E., Heidelbach, F., Hiraga, T. and J.

631 Hustoft, 2003, Melt segregation and strain partitioning: implications for seismic anisotropy 632 and mantle flow. Science, 301, 1227-1230, doi: 10.1126/science.1087132.

633 Ildefonse, B., billau, S., and Nicolas, A., A detailed study of mantle flow away from diapirs in 634 the Oman ophiolite, 1995, in R.L.M. Vissers and A. Nicolas (eds), Mantle and lower crust 635 exposed in oceanic ridges and in ophiolites, Kluwer Academic Publishers, Dordrecht, 163636177.

637 Jousselin, D., Nicolas, A., Boudier, F., 1998, Detailed mapping of a mantle diapir below a 638 paleo-spreading center in the Oman ophiolite, Journal of Geophysical Research, 103, 18153639 18170, doi:10.1029/98JB01493.

640 Jousselin, D., Mainprice D., 1998, Melt topology and seismic anisotropy in the mantle 641 peridotites of the Oman ophiolite, Earth and Planetary Science Letters, 164, 553-568, 642 doi:10.1016/S0012-821X(98)00235-0. 
643 Jousselin, D., Nicolas, A., 2000, The Moho transition zone in the Oman ophiolite-relation

644 with wehrlites in the crust and dunites in the mantle, Marine Geophysical Researches, 21, 645 229-241, doi: 10.1023/A:1026733019682.

646 Jung, H., and S. Karato, 2001. Water-induced fabric transition in olivine, Science, 293, 1460 647 1463, doi: 10.1126/science.1062235.

648 Karson, J.A., Collins, J.A., Casey J., 1984, Geologic and seismic velocity structure of the 649 crust/mantle transition in the Bay of Islands ophiolite complex, Journal of Geophysical 650 Research, 89, 6126-6138, doi:10.1029/JB089iB07p06126.

651 Kelemen, P.B., Koga, Shimizu, N., 1997a, Geochemistry of gabbro sills in the crust-mantle 652 transition zone of the Oman ophiolite: implications for the origin of the oceanic lower crust, 653 Earth and Planetary Science Letters, 146, 475-488, doi:10.1016/S0012-821X(96)00235-X. 654 Kelemen P.B., Hirth G., Shimizu N., Spiegelman M., Dick H.J.B., 1997b, A review of melt 655 migration processes in the adiabatically upwelling mantle beneath oceanic spreading ridges, 656 Phil. Trans. R. Soc. Lond. A, 355(1723), 283-318 doi 10.1098/rsta.1997.0010.

657 Koga, K.T., Kelemen, P.B., Shimizu, N., 2001, Petrogenesis of the crust-mantle transition 658 zone and the origin of lower crustal wehrlite in the Oman ophiolite, Geochemistry-

659 Geophysics-Geosystems, 2, 1038, doi:10.1029/2000GC000132.

660 Komnik, A., Harting, J., Herrmann, H.J., 2004, Transport phenomena and structuring in shear 661 flow of suspensions near solid walls, Journal of statistical mechanics: theory and experiment, 662 doi: 10.1088/1742-5468/2004/12/P12003.

663 Korenaga J., Kelemen, P.B., 1997, Origin of gabbro sills in the Moho transition zone of the 664 Oman ophiolite: Implications for magma transport in the oceanic lower crust, Journal of 665 Geophysical Research, 102, 27,729-27,749, doi:10.1029/97JB02604.

666 Lago, B., Rabinowicz, M., Nicolas, A., 1982, Podiform chromite ore bodies: a genetic model. 667 Journal of Petrology, 23, 103-125, doi:10.1093/petrology/23.1.103. 
Lissenberg, C.J., Bédard, J.H., van Staal, C.R., 2004, The structure and geochemistry of the gabbro zone of the Annieopsquotch ophiolite, Newfoundland: Implications for lower crustal accretion at spreading ridges, Earth and Planetary Science Letters, 229, 105-123, doi:10.1016/j.epsl.2004.10.029.

May, L.B.H., Golick, L.A., Phillips, K.C., Shearer, M., K.E. Daniels, 2009, Shear-driven size segregation of granular materials: modeling and experiment, Physical Review E, 81-5 pt 1, p. 051301.

McBirney, A.R., Nicolas, A.,1997, The Skaergaard layered series. Part II. Magmatic flow and dynamic layering, Journal of petrology, 38, 569-580, doi:10.1093/petroj/38.5.569.

Michibayashi, K., Gerbert-Gaillard, L. and Nicolas, A., 2000, Shear sense inversion in the Hilti mantle section (Oman ophiolite) and active mantle uprise, Marine Geophysical Research, 21, 3-4, 259-268, doi: 10.1023/A:1026713909204.

Morales, F. G., F. Boudier, A. Nicolas, 2011, Dynamics of melt lens and subsidence of axial magma chamber, Tectonics, 30, TC2011, doi:10.1029/2010TC002697.

Myers, J., 1978, Formation of banded gneisses by deformation of igneous rocks, Precambrian Research, 6, 43-64, doi:10.1016/0301-9268(78)90054-2.

Nedimovic, M., Carbotte, S., Harding, A., Detrick, R., Canales, J.P., Diebold, J., Kent, G., Tisher, M., J. Babcock, 2005, Frozen magma lenses below the oceanic crust, Nature, 436, 1149-1152.

Nicolas, A. Prinzhofer, A., 1983, Cumulative or residual origin for the transition zone in ophiolites: Structural evidence, Journal of petrology, 24, 188-206, doi:10.1093/petrology/24.2.188.

Nicolas, A., 1986, A melt extraction model based on structural studies in mantle peridotites, Journal of petrology, 27, 999-1022, doi:10.1093/petrology/27.4.999. 
692 Nicolas, A., Reuber, I., Benn, K., 1988, A new magma chamber model based on structural

693 studies in the Oman ophiolite, Tectonophysics, 151, 87-105, doi:10.1016/0040-

694 1951(88)90242-9.

695 Nicolas, A., 1992, Kinematics in magmatic rocks with special reference, to gabbros. Journal 696 of Petrology 33, 891-915, doi:10.1093/petrology/33.4.891.

697 Nicolas, A., Boudier, F., Ildefonse, B., 1996, Variable crustal thickness in the Oman ophiolite, 698 implication for oceanic crust, Journal of Geophysical Research, 101, 17,941-17,950, 699 doi:10.1029/96JB00195.

700 Plantard, G., Saadaoui, H., Snabre, P., Pouligny, B., 2006, Surface-roughness-driven 701 segregation in a granular slurry under shear, Europhys. Lett., 75(2), 335-341, doi: 702 10.1209/epl/12006-10088-6.

703 Quick, J.E., Denlinger, R.P., 1993, Ductile deformation and the origin of layered gabbro in 704 ophiolites, Journal of Geophysical Research, 98, 14015-14027, doi:10.1029/93JB00698. 705 Ramsay,J.G., Graham, R.H., 1970, Strain variation in shear belt, Can. J. Earth Sci., 7, 786706 813, doi: 10.1139/e70-078.

707 Rabinowicz M., Ceuleneer G., Nicolas A., 1987, Melt segregation and asthenospheric flow in 708 diapirs below spreading centers: evidence from the Oman ophiolite. Journal of Geophysical 709 Research, 92, 3475-3486, doi:10.1029/JB092iB05p03475.

710 Sano S., Kimura, J.-I., 2007, Clinopyroxene REE geochemestry of the Red Hills peridotites, 711 New Zealand: interpretation of magmatic processes in the upper mantle and in the Moho 712 transition zone, Journal of petrology, 48, 113-139, doi:10.1093/petrology/eg1056.

713 Santra, S.B., Schwarzer, S., Hermann, H., 1996, Fluid-induced particle size segregation in 714 sheared granular assemblies, Physical Review E., 54, 5, 5066-5072.

715 Serront, 1993, Déformation expérimentale à haute pression et haute température d'aggrégats 716 polycristallins de plagioclase et d'olivine. Thèse de Doctorat, Montpellier, 237p. 
717 Sinton, J.M., 1977, Equilibration history of the basal alpine-type peridotite, Red Mountains,

718 New Zealand, Journal of petrology, 18, 216-246, doi:10.1093/petrology/18.2.216.

719 Smewing, J.D., 1981, Mixing characteristics and compositional differences in mantle-derived

720 melts beneath spreading axes: evidences from cyclically layered rocks in the ophiolite of

721 North Oman, Journal of Geophysical Research, 86, 2645-2659,

722 doi:10.1029/JB086iB04p02645.

723 Sokolowski S., Herrmann, H.J., 1992, Dynamic phase separation of a fluid mixture,

724 Europhysics Letters, 18, 5, 415-420.

725 Suhr, G., E. Hellebrand, K. Johnson, Brunelli D., 2008, Stacked gabbro units and intervening

726 mantle: A detailed look at a section of IODP Leg 305, Hole U1309D, Geochem. Geophys.

727 Geosyst., 9, Q10007, doi:10.1029/2008GC002012

728 Molen, I. Paterson, M.S., 1979, Experimental deformation of partially-melted granite.

729 Contributions to Mineralogy and Petrology, 70, 299-318, doi: 10.1007/BF00375359.

730 Vernon, R.H., 2000, Review of microstructural evidence of magmatic and solid-state flow,

731 Electronic Geosciences, 5:2, doi: 10.1007/s10069-000-0002-3.

732 Yaouancq, G., MacLeod, C.J., 2000, Petrofabric investigation of gabbros from the Oman

733 ophiolite: comparison between AMS and rock fabric, Marine Geophysical Researches, 21,

734 289-305, doi: 10.1023/A:1026774111021.

Tab and figure caption

Table 1: Modal composition at the thin section scale for a selection of our samples. See the

740 microstructural analysis paragraph for the definition of gabbro type. Modal composition

741 within different layers is provided when layer boundaries are observed within the thin section. 
743 Figure 1: 3 views on layered gabbro lenses at outcrop/sample/thin section scales. A) A series

744 of $10-40 \mathrm{~cm}$ thick layered gabbro lenses embedded in dunite. Hammer handle is $40 \mathrm{~cm}$. B)

745 Close up views on layers within a lens, with sharp and linear boundaries (referred as type 4 in

746 the text). Pictures height is $30 \mathrm{~cm}$. C) Thin section phase maps of samples 07OD48 (top) and

747 07OD47B3 (bottom) constructed from MEB-EBSD measurements (N.I.: not indexed).

749 Figure 2: views on isotropic, poorly layered, and irregular-shaped gabbro layers and patches.

750 A) Isotropic gabbro at the center of the Khilah outcrop. B) Dunitic small bodies with random 751 orientations and diffuse contacts within isotropic gabbro at the Khilah outcrop. C-D) Two

752 examples of $1 \mathrm{~m}$-long rough layers emerging from isotropic gabbro (referred as type 2 in the 753 text). E-F) slightly better developed layering, with wavy boundaries and frequent layer 754 terminations (referred as type 3 in the text) G) Several discordant layers H) small altered 755 gabbroic lens with an irregular shape, with its longest axis approximately parallel to the 756 stretching lineation in host dunite.

758 Figure 3: A) Lineation map of the Maqsad diapir (adapted from Jousselin et al, 1998) with 759 samples distribution. B) close up on the situation of the Khilah outcrop; location shown by a 760 rectangle in A. The Khilah outcrop is the southernmost and largest circled isotropic gabbro 761 outcrop. C) Boulders collected at the Khilah outcrop, with progressive increase in plagioclase 762 and clinopyroxene content, mimicking the diffuse transition from impregnated dunite to 763 gabbro. D) Field sketch of the eastern part of the Khilah outcrop; location shown by a grey 764 rectangle in B); the western part is more monotonous with essentially isotropic gabbro. 
Figure 4: close up on melt impregnated dunite at the periphery of the Khilah outcrop. A)

767 plagioclase and clinopyroxene impregnated dunite in the MTZ near the Mahram pass (see Fig. 3B), with a few automorphic plagioclase grains (pointed by arrows). B) plagioclase oikocrysts isolating olivine grains in the impregnated dunite at the western limit of the Khilah outcrop.

Figure 5: from bottom to top, (1) foliated plagioclase impregnations in dunite, (2) three $1 \mathrm{~cm}$ bands, rich in plagioclase aggregates of impregnating crystals, and (3) thin lenses of layered gabbro (type 4) in the background.

Figure 6: kinematic indicators of simple shear in layered gabbro lenses. A-B) Asymmetrical folds; as is the case for strong deformation, fold axis are rotated parallel to the lineation direction. C-D) Normal shear zones in cross-section and planar view. The planar view shows the consistent orientation of the shear plane, and the cross-section view explains the color variations in map view induced by the movement at the shear zone. E) Close-up view on a layer with olivine crystals at a consistent angle to the layering.

Figure 7: a selection of fabrics and shape fabrics from our microstructural study. A) Olivine CPO for a dunite (host rock of the gabbro lenses) showing a classic [100] (010) mantle fabric. The obliquity between the $[100]$ axis and the lineation $[\mathrm{X}]$ indicates a dextral shear sense. B) Histograms of the orientation of the long axis in $\mathrm{XZ}$ thin sections of plagioclase grains for four samples. The lineation corresponds to the $90^{\circ}$ orientation. As deformation progress from type 1 to type 4 gabbros, measurements show a better shape preferred orientation parallel to the lineation. C) CPO of olivine and plagioclase for 6 samples, showing deformation evolution in the 4 sample types. Type 1 samples show no CPO; type 2 samples show a planar fabric defined by the (010) planes of olivine and plagioclase; type 3 samples show a [001] 
791 (010) olivine and [100] (010) plagioclase magmatic fabric, with a lineation superimposed on

792 the planar fabric. Type 4 gabbros are characterized by a switch to olivine plastic deformation

793 with a strong [100] lineation. Contours are at $0.5 \%$ intervals of uniform distribution.

794

795 Figure 8: model for the formation of layered gabbro lenses. The model relies on the

796 correlations of gabbro lenses shape changes, the absence of layering in type 1 gabbro and the

797 development of layering from type 2 to type 4 gabbros, and the evolution of the fabric due to

798 the host mantle (gray) shearing; it implies melt (white) delivery from dikes, and integration of

799 mantle olivine within layered gabbros 
Melt impregnation forms isotropic gabbro in the Oman ophiolite Moho transition zone We measured crystallographic fabric for transition from isotropic to layered gabbro Olivine fabric evolves from planar to [001](010)-magmatic to [100](010)-HTplastic We deduce that gabbro layering originates from shear caused by host mantle flow Isotropic stage means melt collected faster than shear rate, thus extracted by dikes 

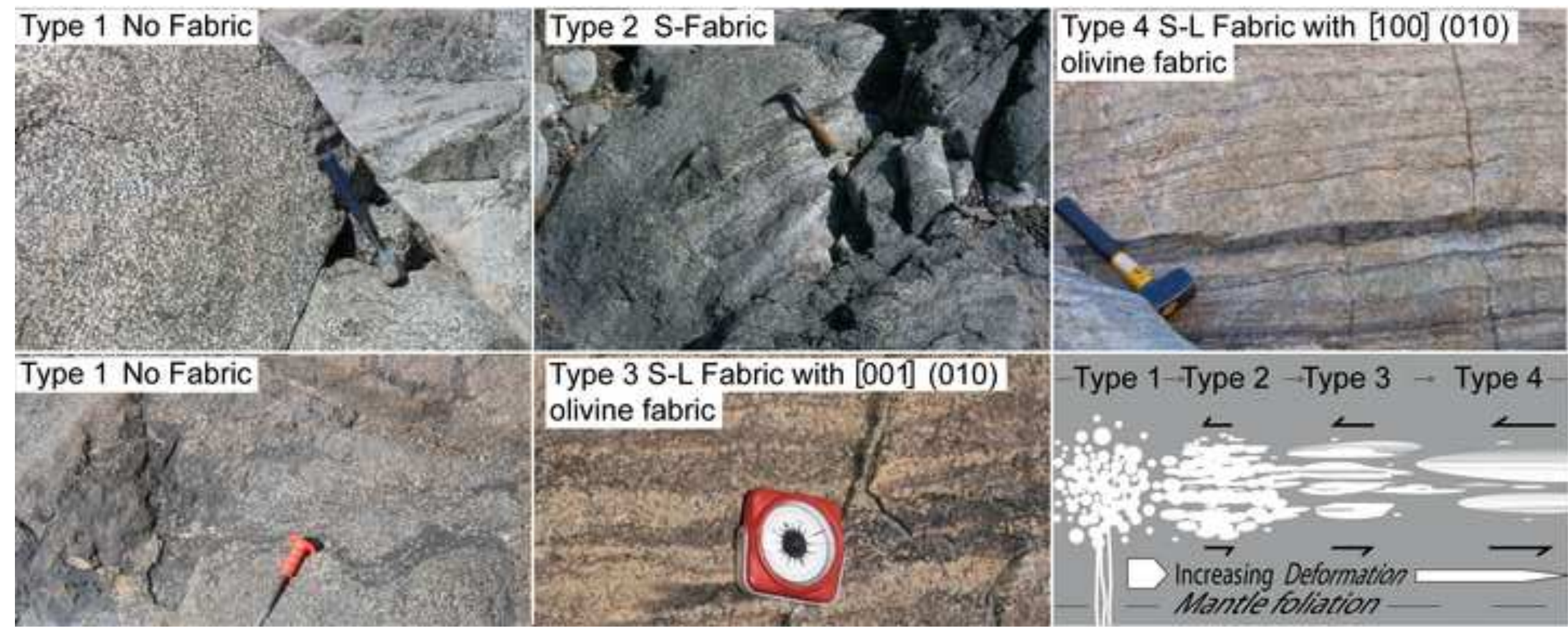

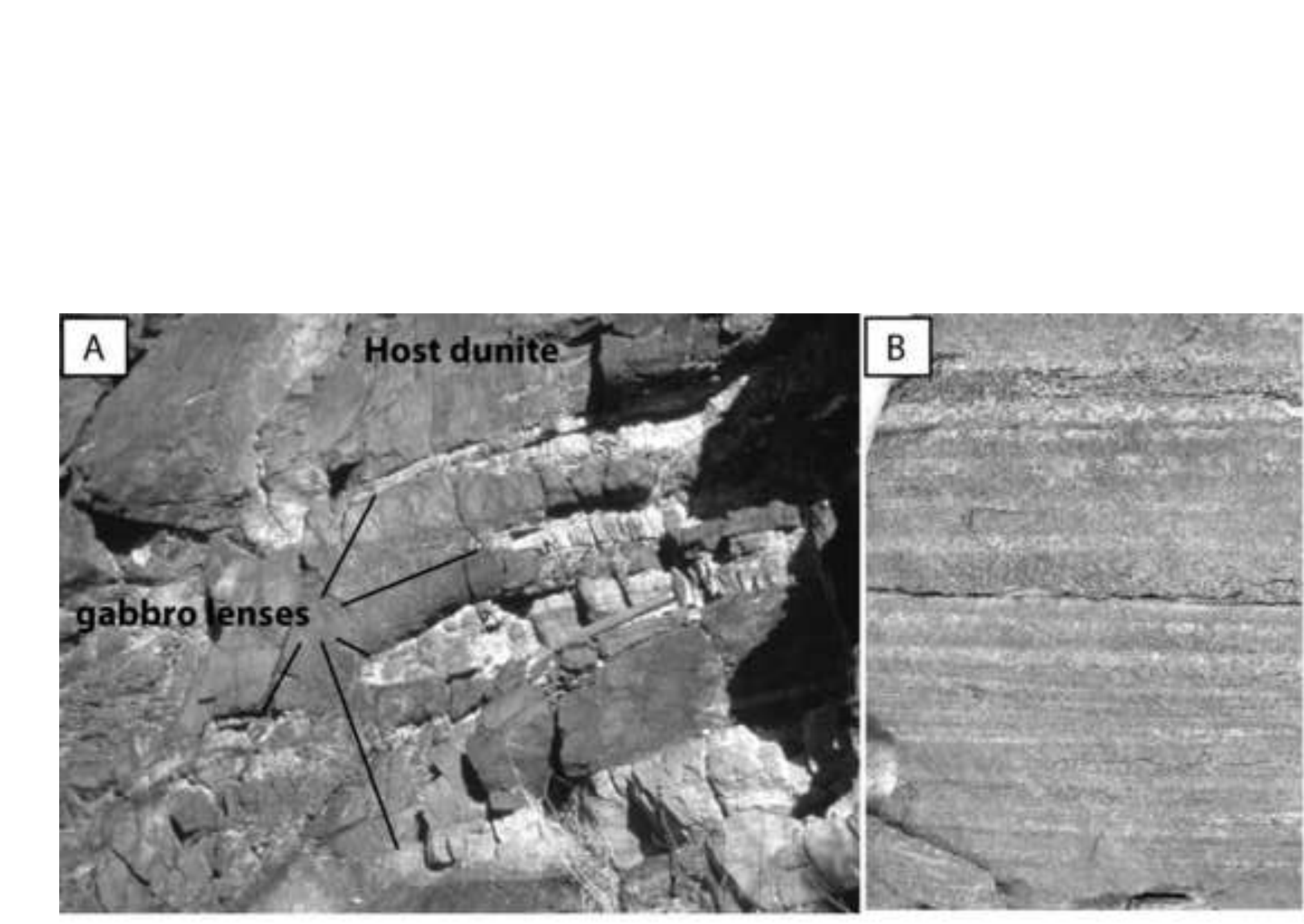

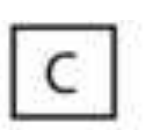

미.

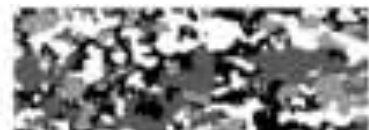
oxotion 50 ateseres

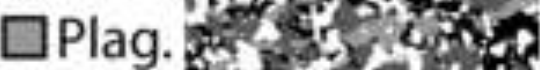
$\square C p x$.

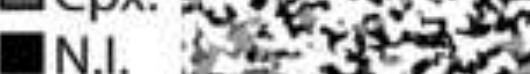

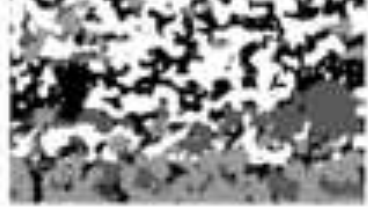

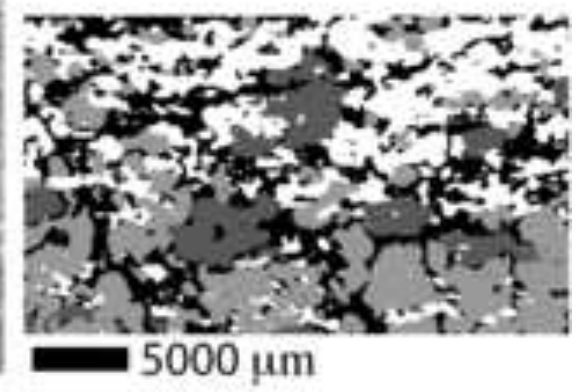

N.I.

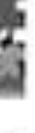
(

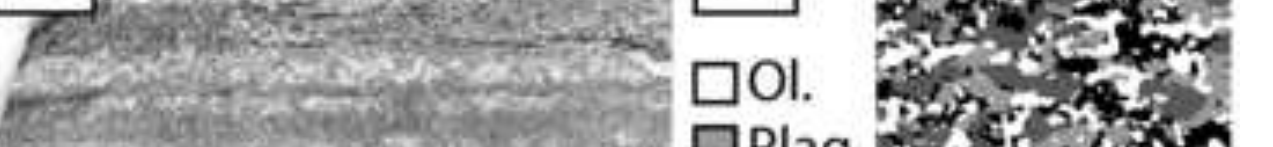



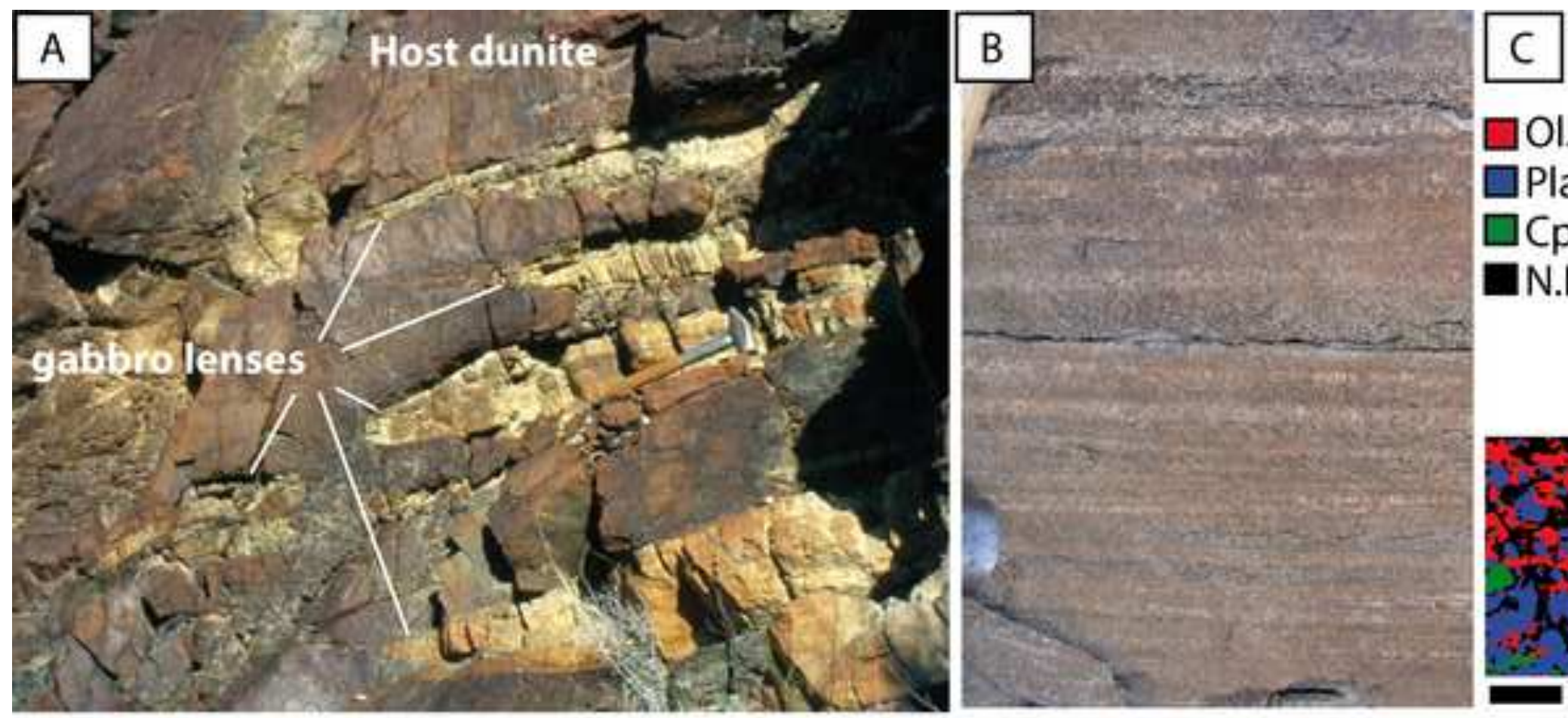

$\square \mathrm{OI}$.

$\square$ Plag.

$\square$ Cpx.

N.I.
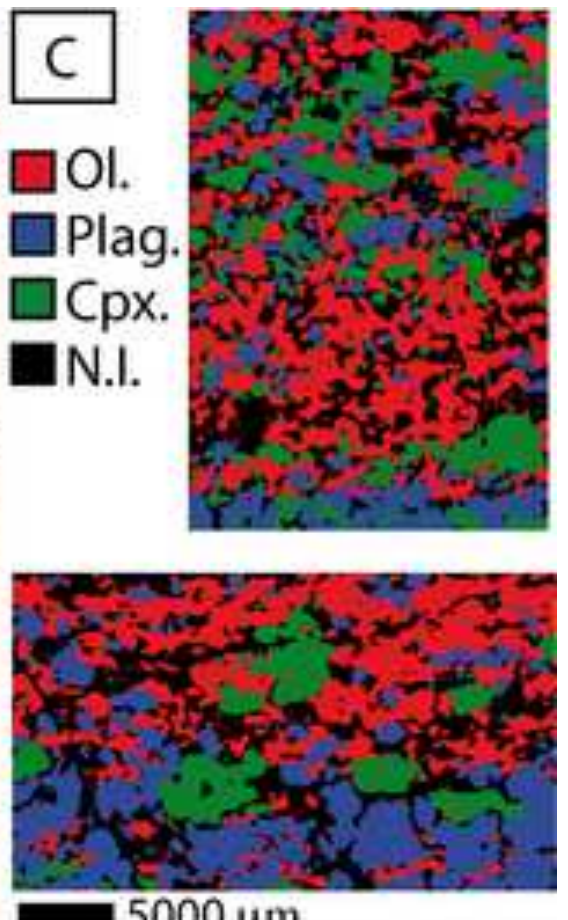

$5000 \mu \mathrm{m}$ 

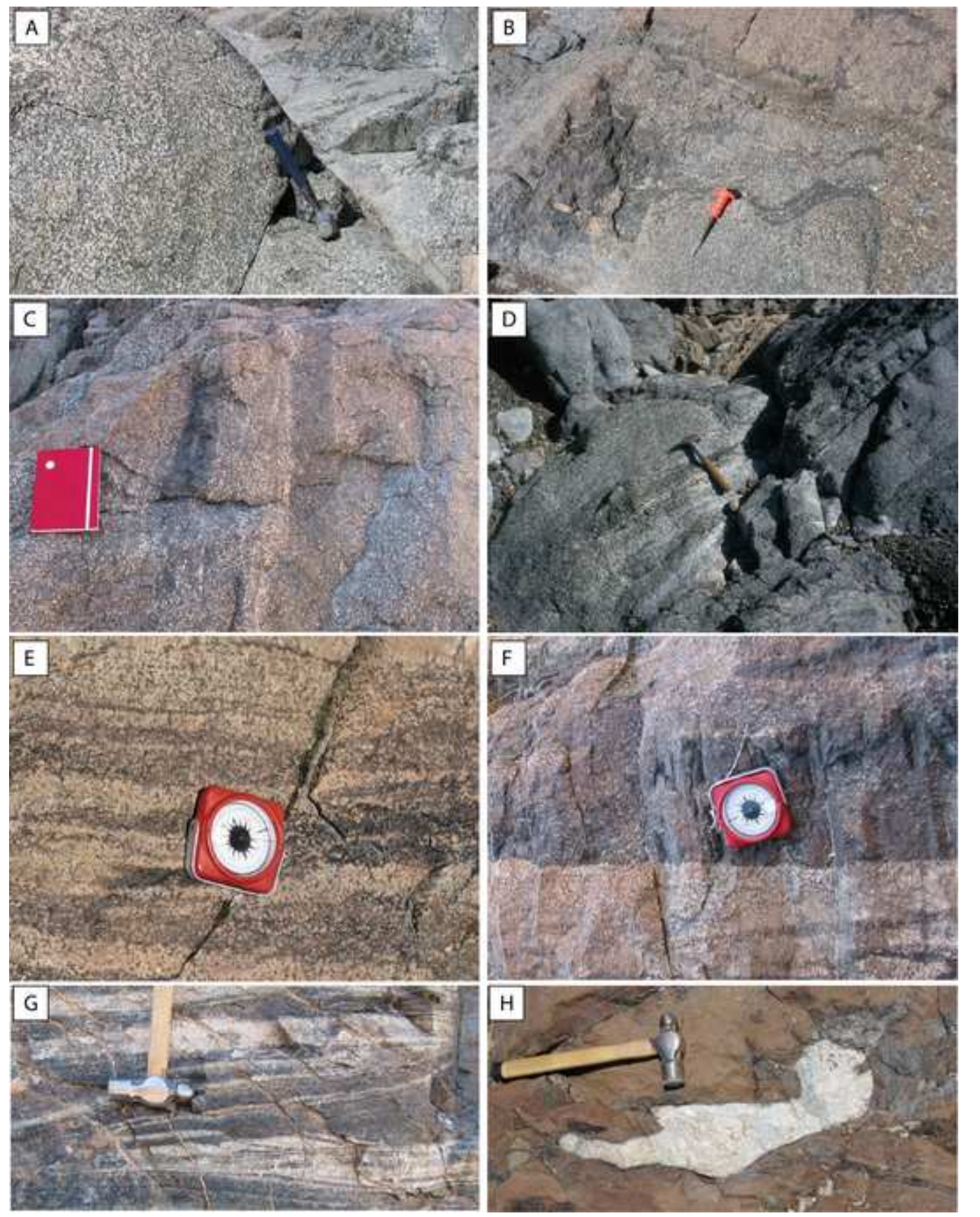


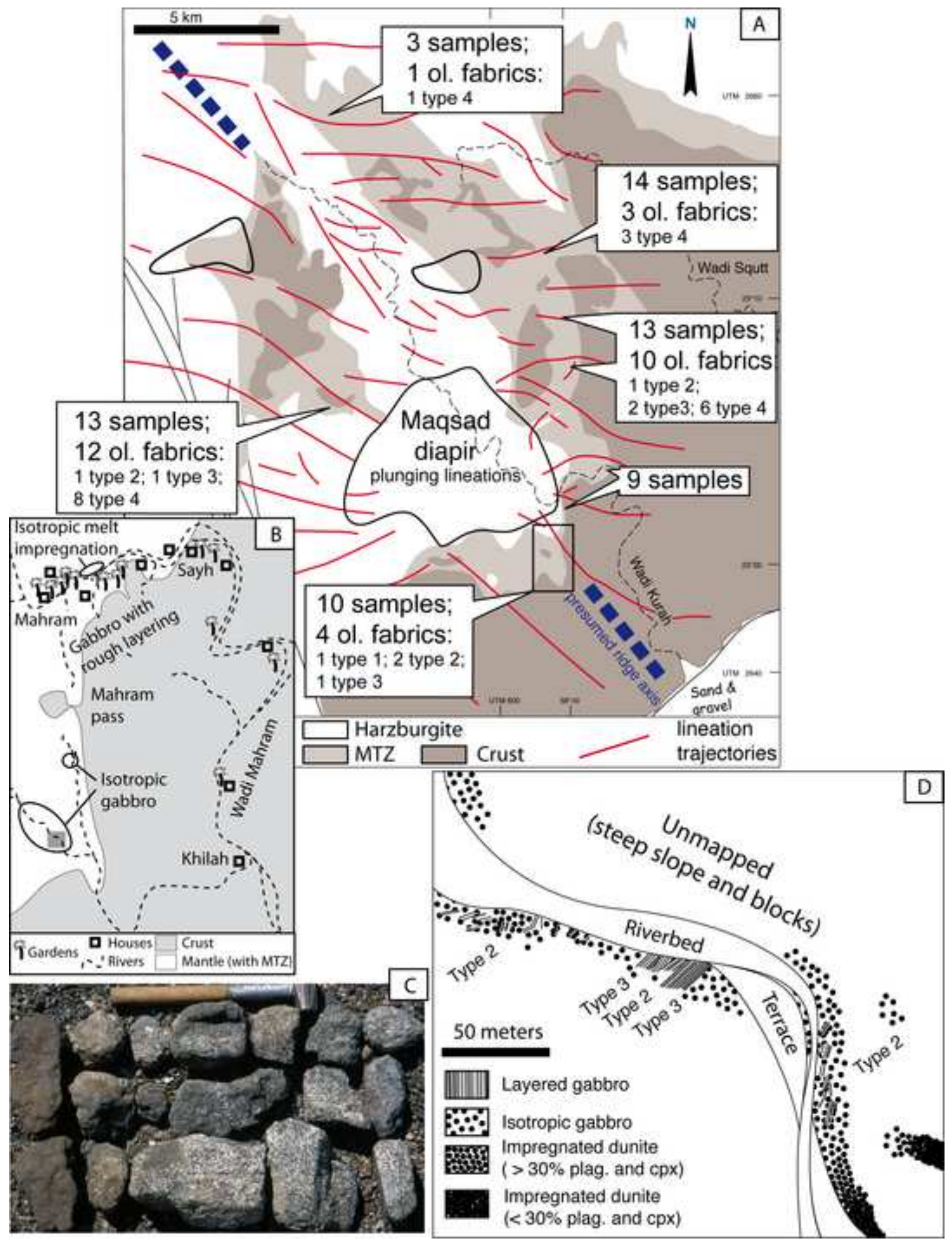

Figure 3 (can be printed in $B \& W$ )

12 ol. fabrics:

1 type 2; 1 type 3:

sotropic melt

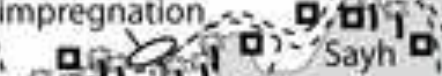
Mähra $(60000)$ eing 1

Isotropic

C 

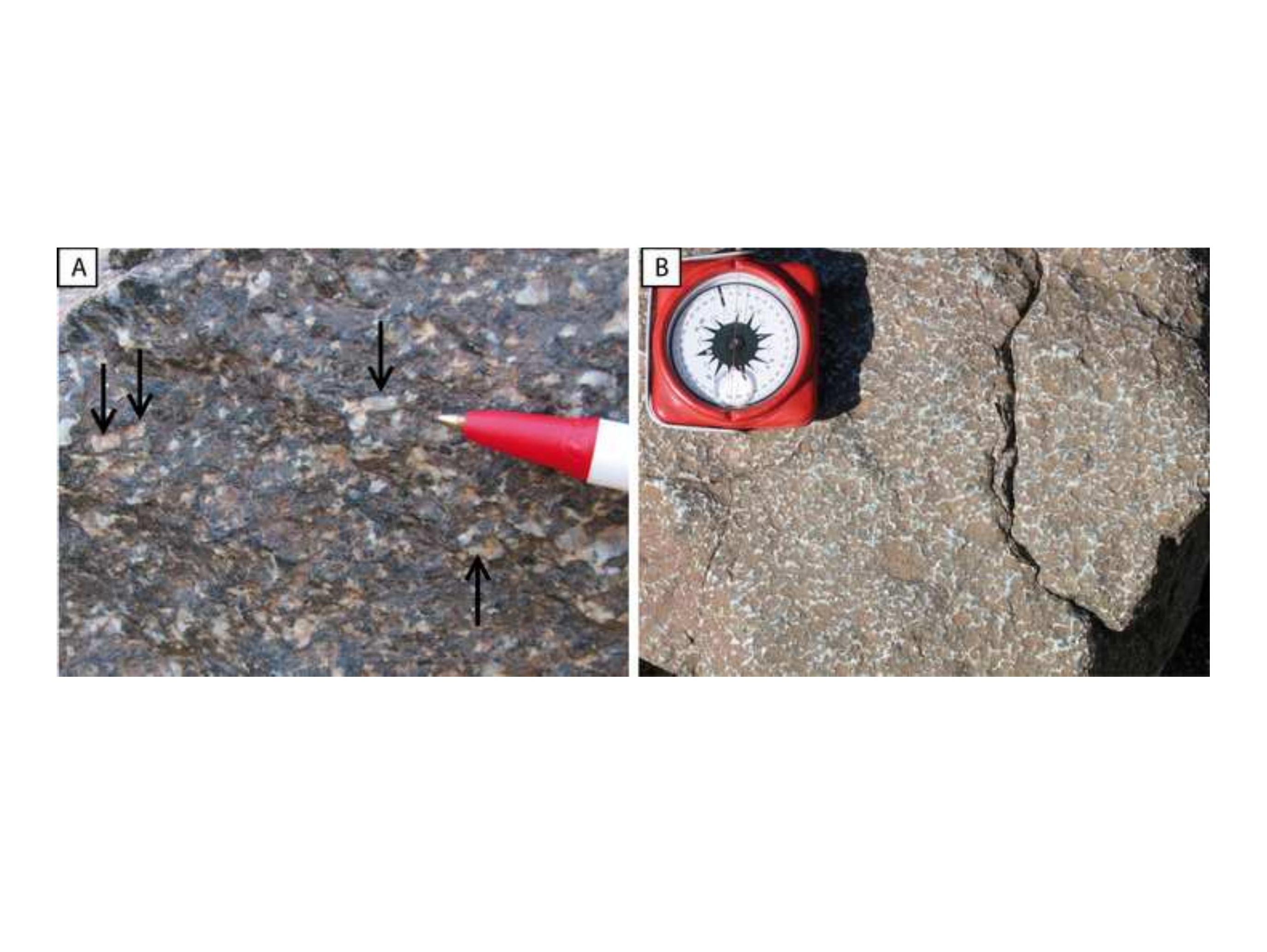


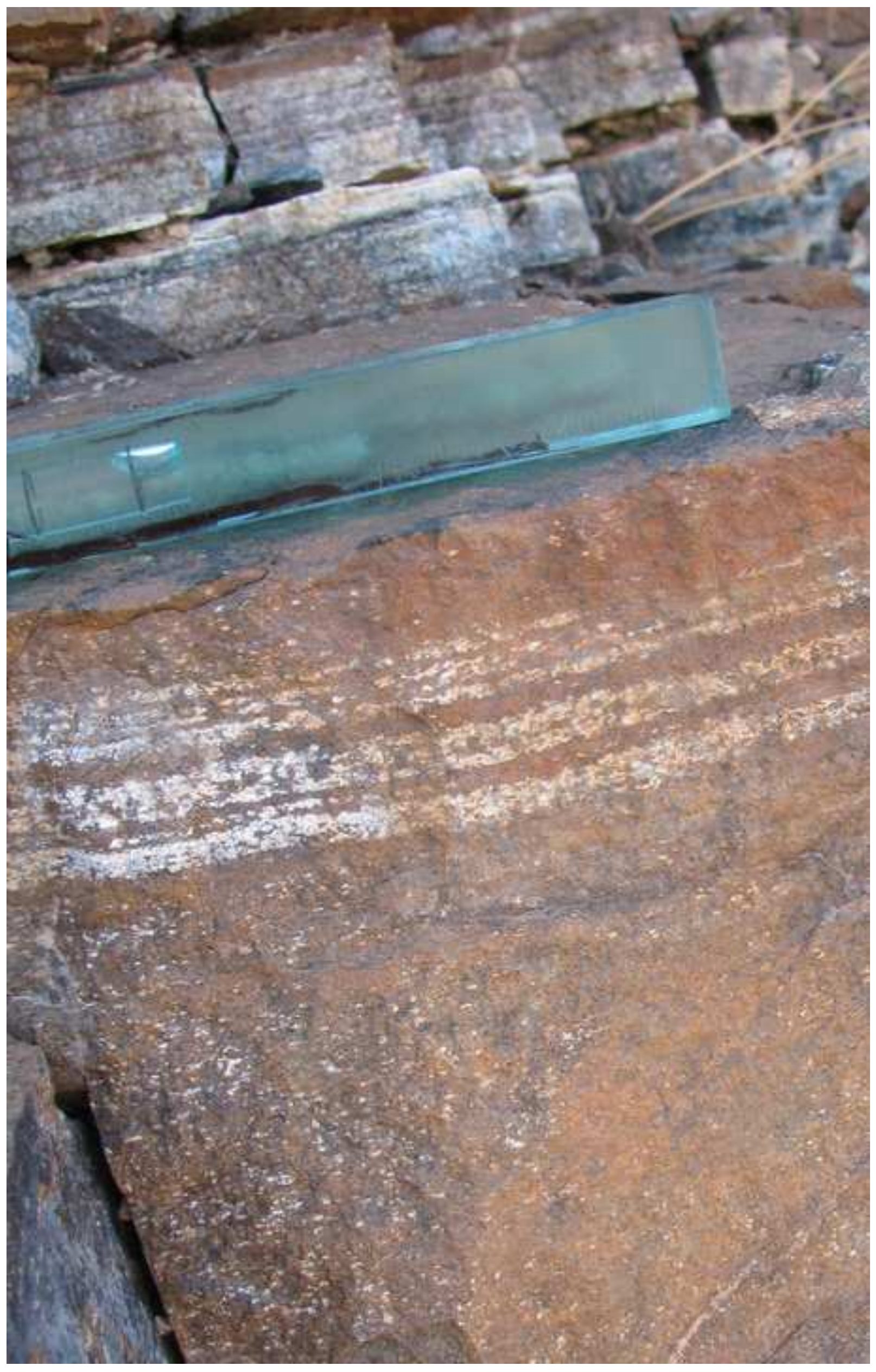

Figure 5 (can be printed in $B \& W$ )

\section{Figure 5 (can}
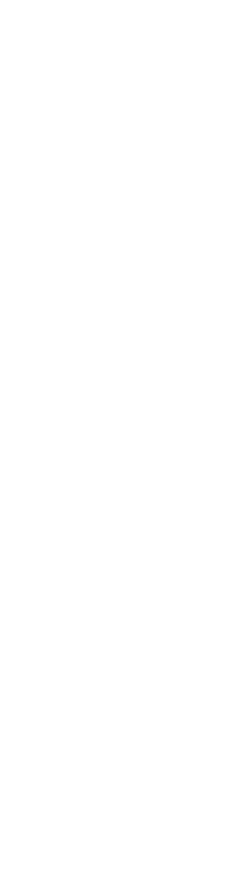

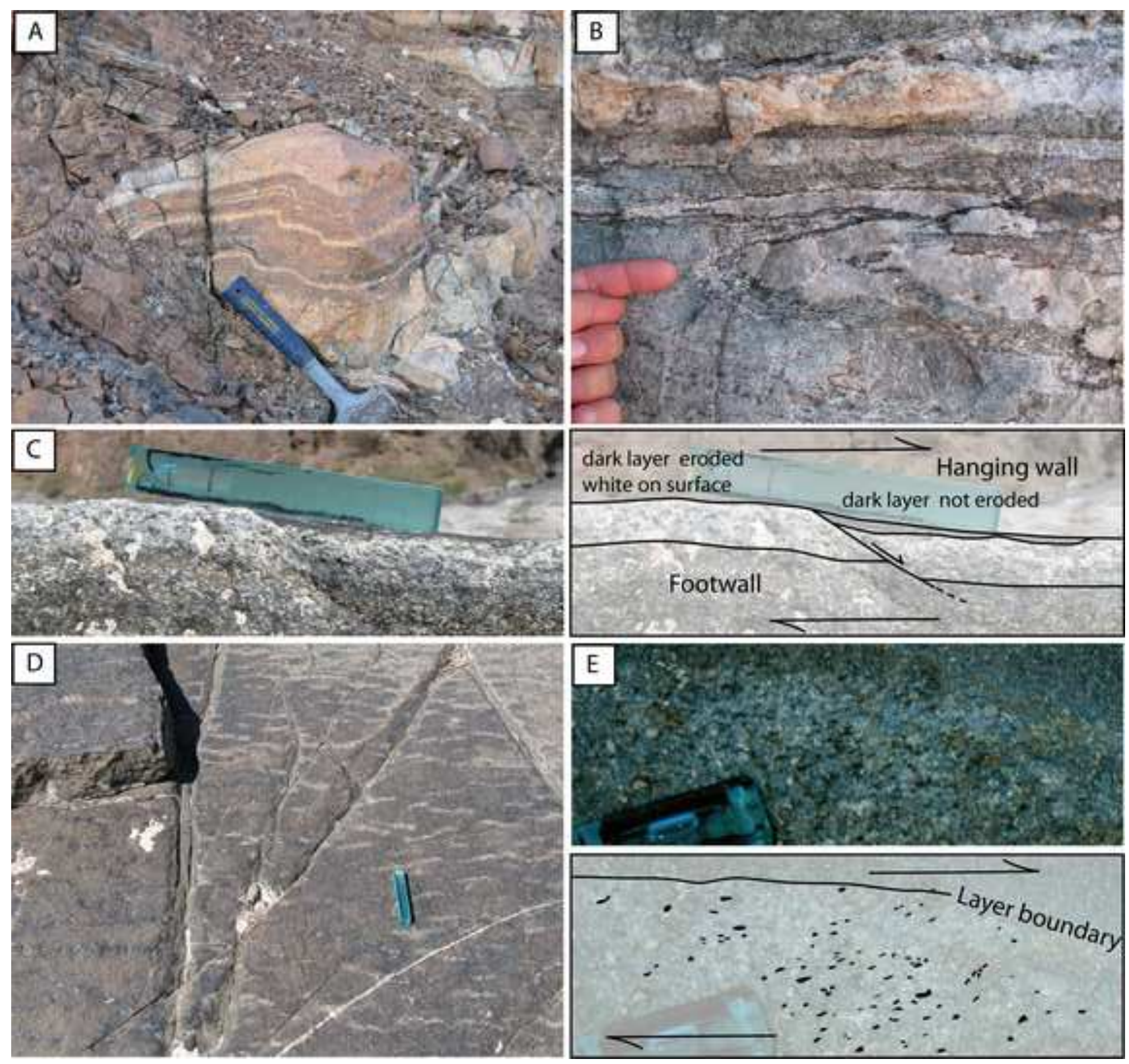

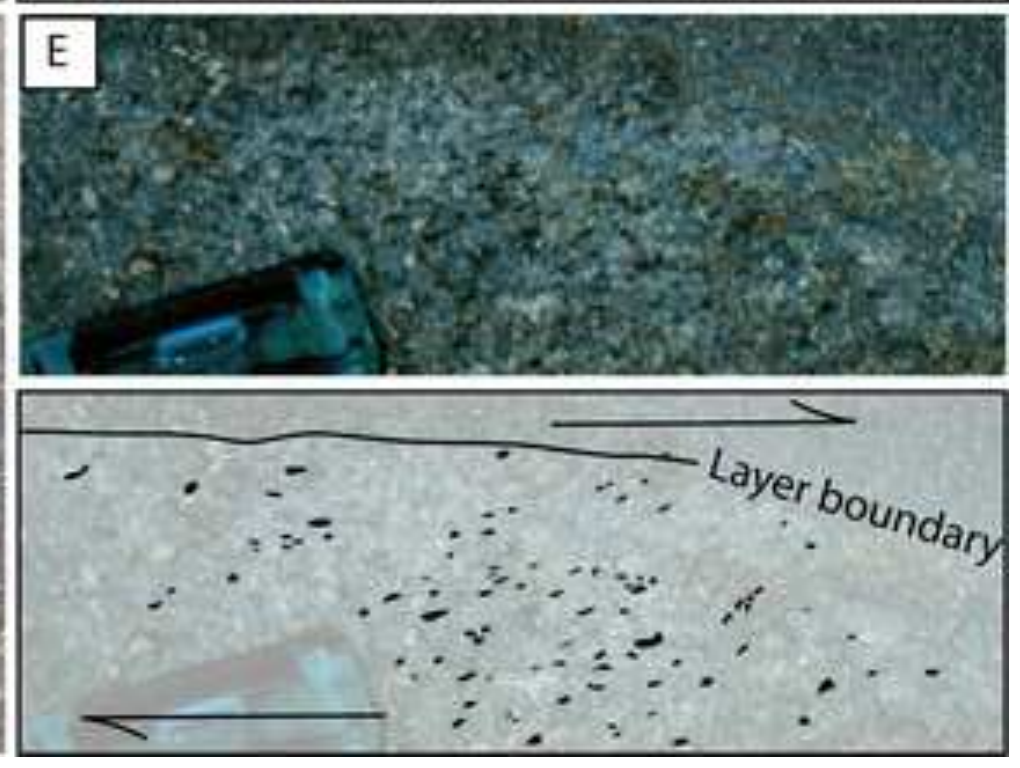

white on surface dark layer not eroded 
Figure 7 (can be printed in $B \& W$ )
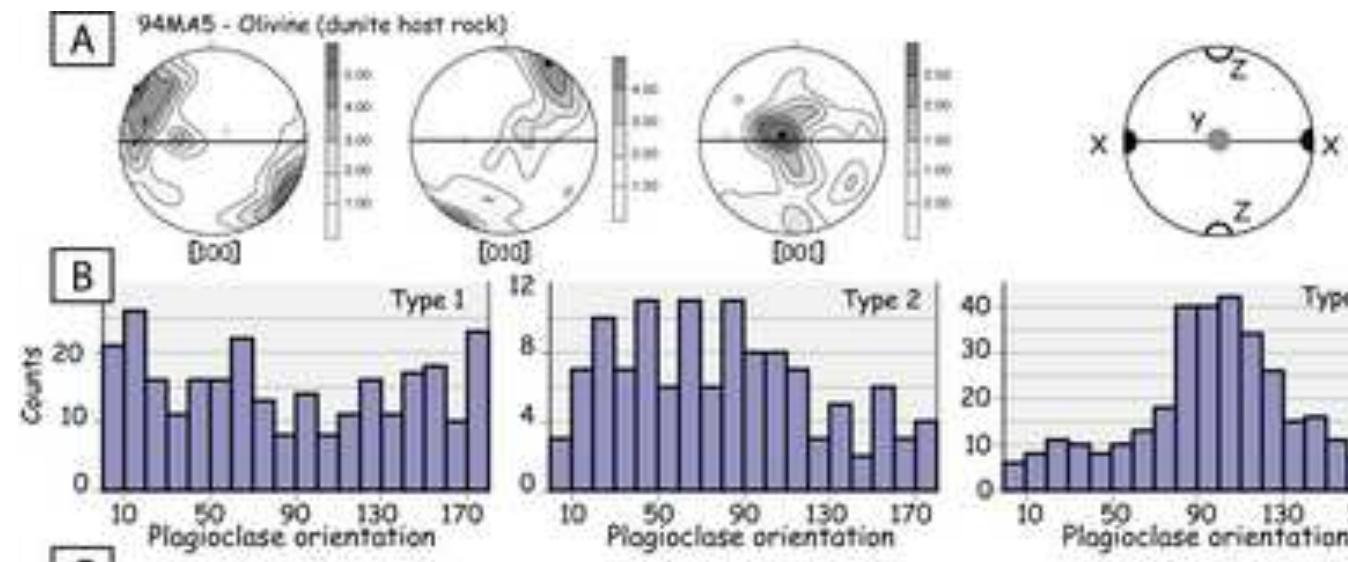

C. 0700440. Olivine

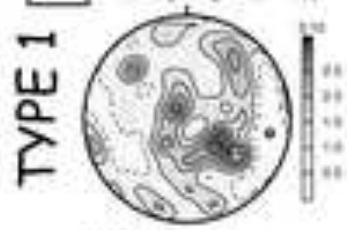

orob44E - Olivine
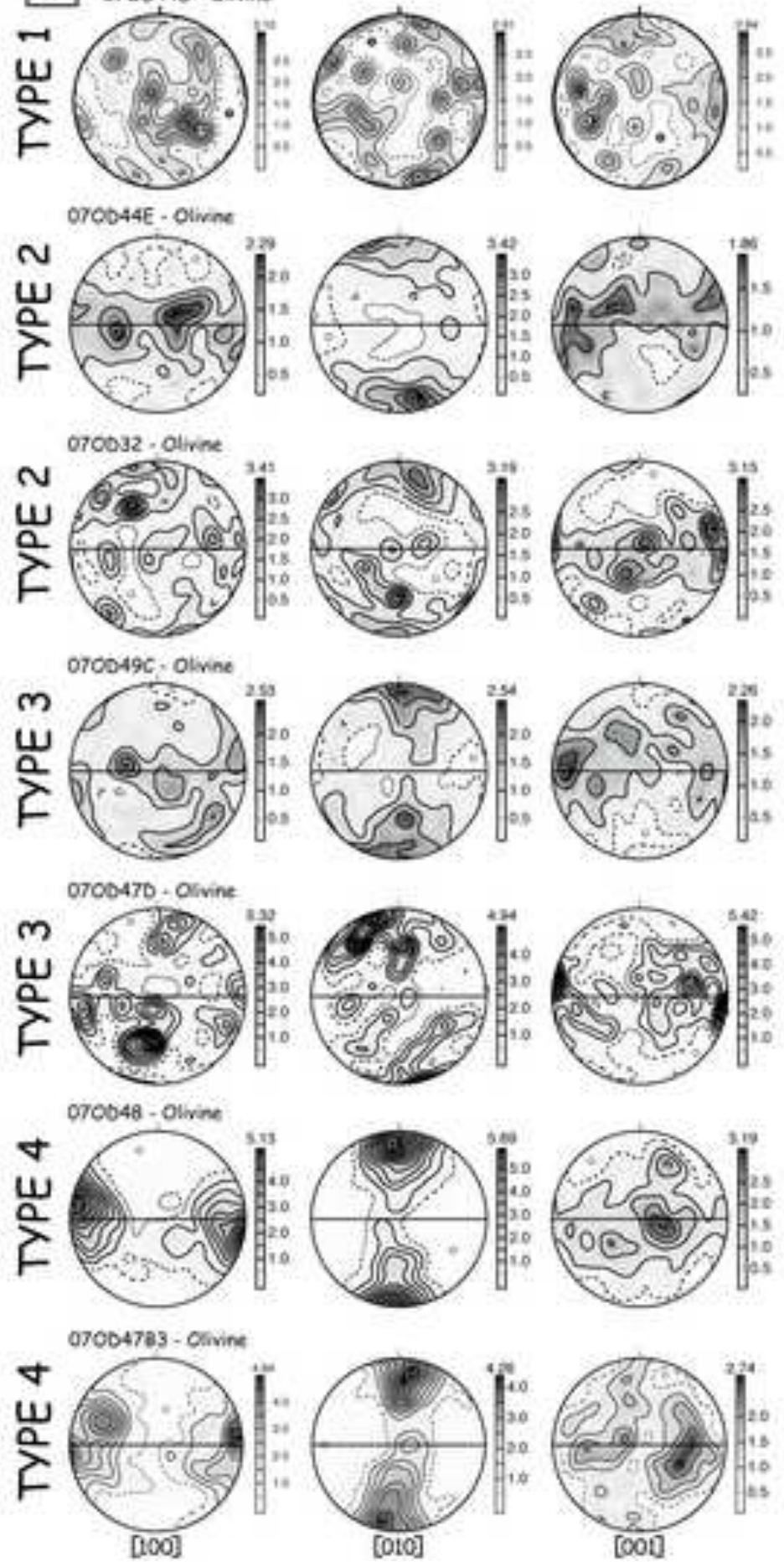

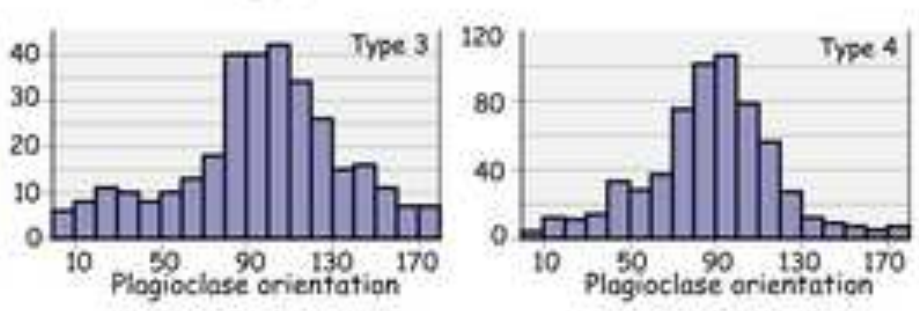

0700440 - Plogisclase

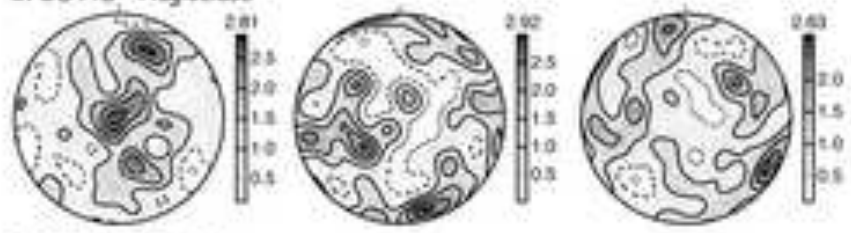

orob4te + Plogioclase

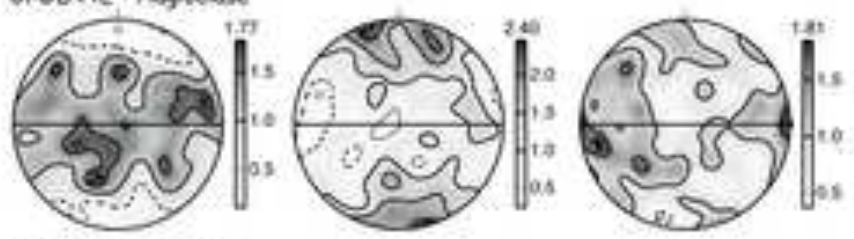

aroo32. Plogioclose.

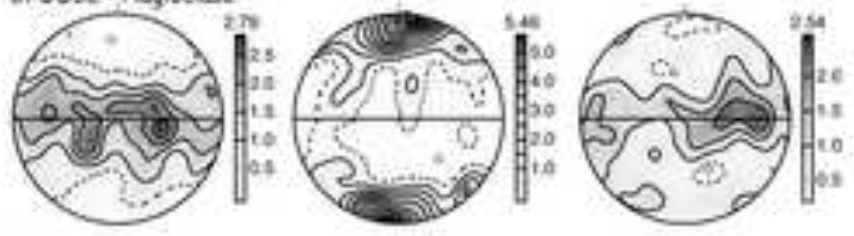

070069C - Fiogieclose

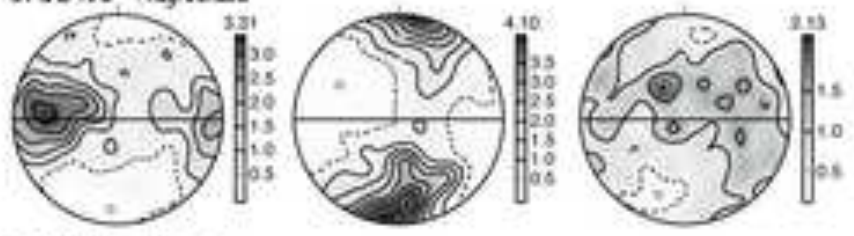

0700470 - Plogioclase

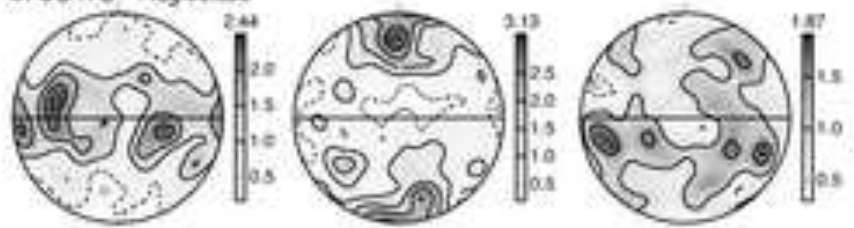

070045 - Plogisclase

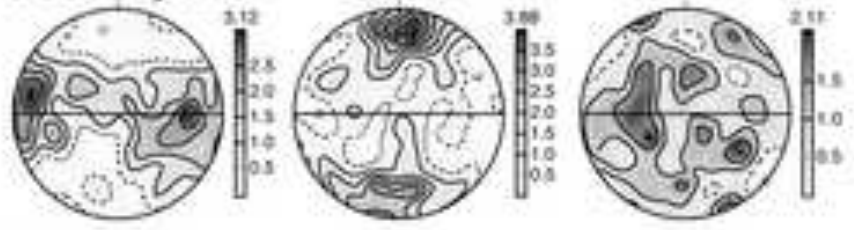

07004783 - Plogioclose

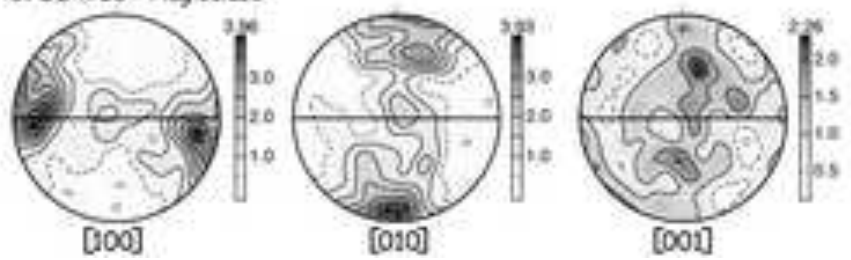




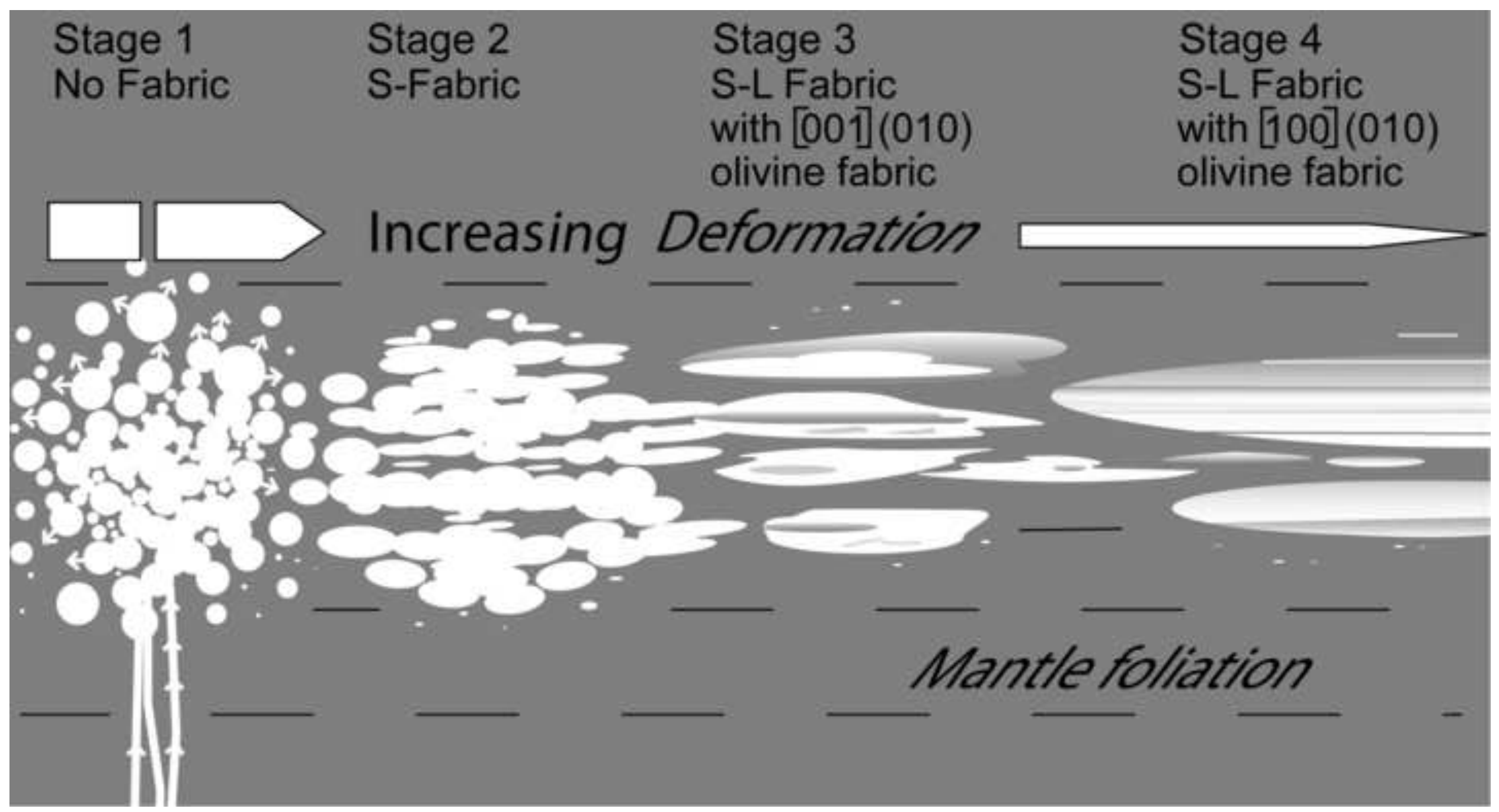




\begin{tabular}{|c|c|c|c|}
\hline $\begin{array}{l}\text { Sample/ } \\
\text { layers }\end{array}$ & Type & \multicolumn{2}{|c|}{$\begin{array}{c}\text { Modal composition } \\
\text { Global/layer ol-plag-cpx }\end{array}$} \\
\hline $\begin{array}{l}\text { 07OD44D } \\
\text { unlayered }\end{array}$ & 1 & \multicolumn{2}{|c|}{$15-75-10$} \\
\hline $\begin{array}{l}\text { 07OD49E } \\
\text { unlayered }\end{array}$ & 1 & \multicolumn{2}{|c|}{ 22-78-0 } \\
\hline $\begin{array}{c}\text { 07OD44B } \\
1 \text { layer }\end{array}$ & 2 & \multicolumn{2}{|c|}{$15-76-9$} \\
\hline $\begin{array}{l}\text { 07OD44E } \\
1 \text { layer }\end{array}$ & 2 & \multicolumn{2}{|c|}{ 14-89-1 } \\
\hline $\begin{array}{l}\text { 07OD21B } \\
1 \text { layer }\end{array}$ & 2 & \multicolumn{2}{|c|}{$19-77-4$} \\
\hline $\begin{array}{l}\text { 07OD32 } \\
2 \text { layers }\end{array}$ & 2 & $40-60-0$ & $\begin{array}{l}34-66-0 \\
56-43-0\end{array}$ \\
\hline $\begin{array}{c}\text { 07OD47D2 } \\
\text { 1 layer }\end{array}$ & 3 & \multicolumn{2}{|c|}{ 26-74-0 } \\
\hline $\begin{array}{l}\text { 07OD49C } \\
3 \text { layers }\end{array}$ & 3 & 36-49-15 & $\begin{array}{l}44-56-0 \\
22-17-61 \\
13-86-1\end{array}$ \\
\hline $\begin{array}{l}\text { 10OM26-2 } \\
3 \text { layers }\end{array}$ & 3 & 7-91-2 & $\begin{array}{l}7-91-1 \\
2-96-2 \\
14-82-4\end{array}$ \\
\hline $\begin{array}{l}\text { 10OM43A } \\
1 \text { layer }\end{array}$ & 3 & $11-88-1$ & \\
\hline $\begin{array}{l}070 D 48 \\
3 \text { layers }\end{array}$ & 4 & $46-28-26$ & $\begin{array}{l}3-76-21 \\
68-11-21 \\
37-26-37\end{array}$ \\
\hline $\begin{array}{l}\text { 07OD47B1 } \\
2 \text { layers }\end{array}$ & 4 & 9-61-30 & $\begin{array}{l}8-53-39 \\
11-89-0\end{array}$ \\
\hline $\begin{array}{l}\text { 07OD47B3 } \\
2 \text { layers }\end{array}$ & 4 & $43-40-15$ & $\begin{array}{l}69-19-12 \\
15-65-20\end{array}$ \\
\hline $\begin{array}{l}\text { 07OD47A } \\
2 \text { layers }\end{array}$ & 4 & $40-58-2$ & $\begin{array}{l}12-87-1 \\
95-3-2\end{array}$ \\
\hline $\begin{array}{l}\text { 10OM43L } \\
3 \text { layers }\end{array}$ & 4 & 23-77-0 & $\begin{array}{l}27-71-1 \\
7-93-0 \\
37-63-0\end{array}$ \\
\hline $\begin{array}{l}\text { 10OM26-4 } \\
3 \text { layers }\end{array}$ & 4 & 10-83-7 & $\begin{array}{l}14-76-10 \\
1-96-3 \\
12-82-6\end{array}$ \\
\hline
\end{tabular}



